\title{
NORM waste, cements, and concretes. A review
}

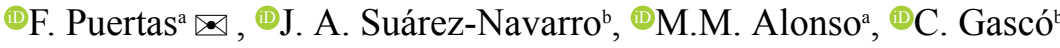 \\ a. Eduardo Torroja Institute for Construction Science (IETcc-CSIC) (Madrid, Spain) \\ b. CIEMAT (Madrid, Spain) \\ puertasf@ietcc.csic.es
}

Received: 01 November 2020

Accepted: 26 November 2020

Available on line: 24 August 2021

\begin{abstract}
The use of industrial waste and/or by-products as alternative sources of raw materials in building materials has become standard practice. The result, more sustainable construction, is contributing to the institution of a circular economy. Nonetheless, all necessary precautions must be taken to ensure that the inclusion and use of such materials entail no new health hazard for people or their environment. Due to the processes involved in generating industrial waste/by-products, these alternative or secondary materials may be contaminated with heavy metals, other undesirable chemicals or high levels of natural radioactivity that may constrain their use. In-depth and realistic research on such industrial waste is consequently requisite to its deployment in building materials. This paper reviews the basic concepts associated with radioactivity and natural radioactivity, focusing on industrial waste/by-products comprising Naturally Occurring Radioactive Materials (NORM) used in cement and concrete manufacture. Updated radiological data are furnished on such waste (including plant fly ash, iron and steel mill slag, bauxite and phosphogypsum waste) and on other materials such as limestone, gypsum and so on. The paper also presents recent findings on radionuclide activity concentrations in Portland cements and concretes not bearing NORMs. The role of natural aggregate in end concrete radiological behaviour is broached. The radiological behaviour of alternative non-portland cements and concretes, such as alkali-activated materials and geopolymers, is also addressed.
\end{abstract}

KEYWORDS: NORM waste; Cements; Concretes; Geopolymers; Radioactivity; Behaviour.

Citation/Citar como: Puertas, F.; Súarez-Navarro, J.A.; Alonso, M.M.; Gascó, C. (2021) NORM waste, cements, and concretes. A review. Mater. Construcc. 71 [344], e259 https://doi.org/10.3989/mc.2021.13520

RESUMEN: Revisión sobre residuos NORM, cementos y hormigones. La utilización de residuos y/o subproductos industriales, como materiales alternativos, en la preparación de materiales de construcción, es una actividad cada día más vigente y normal; y está encaminada a conseguir una construcción más sostenible y alcanzar la deseada Economía Circular. Sin embargo, deben tomarse todas las precauciones necesarias de modo que la incorporación y utilización de estos materiales no suponga una nueva amenaza a la salud de la población y al medio ambiente. Estos residuos y/o subproductos industriales pueden estar enriquecidos (por el propio proceso de su generación) de metales pesados, y otros componentes químicos no deseables; además de altos contenidos de radioactividad natural, lo que puede condicionar negativamente su empleo como materiales alternativos y/o secundarios. Es por ello, que es preciso un estudio muy profundo y realista de dichos residuos y subproductos industriales previo a su utilización en la preparación de materiales de construcción. En este artículo de revisión o estado del conocimiento se hace un repaso a los conceptos básicos de radioactividad y radioactividad natural, centrando el estudio en aquellos residuos y/o subproductos industriales que son residuos NORM (Naturally Occurring Radioactive Materials) y que se emplean en la preparación de cementos y hormigones. Se aportan datos radiológicos actualizados sobre estos residuos y subproductos industriales (ej. cenizas volantes de centrales, térmicas, escorias metalúrgicas, residuos de bauxita, fosfoyeso), y también se dan datos radiológicos de otros materiales como calizas, yesos, etc. Igualmente, se presentan resultados recientes sobre concentraciones de actividad de radionucleidos de cementos y hormigones en base Portland, con distinta composición y contenido en residuos NORM. Se incide en el papel de los áridos naturales en el comportamiento radiológico final de los hormigones. Se aborda, igualmente el comportamiento radiológico de cementos y hormigones alternativos al Portland como son los activados alcalinamente y geopolímeros.

PALABRAS CLAVE: Residuos NORM; Cementos; Hormigones; Geopolymeros; Radioactividad; Comportamiento.

Copyright: (C2021 CSIC. This is an open-access article distributed under the terms of the Creative Commons Attribution 4.0 International (CC BY 4.0) License. 


\section{Outline:}

1. Introduction

2. Radioactivity and natural radioactivity: the basics

2.1. Types of radioactivity

2.2. Naturally occurring radioactive materials (NORM). NORM industries

3. Norm waste used in cement and concrete manufacture

4. Radiological behaviour in NORM waste, cements and concretes

4.1. Coal-fired power plant fly ash and botton ash

4.2. Iron and steel mill slag

4.3. Other waste used as supplementary cementitious materials (SCMs) in cement and concrete manufacture

4.4. Gypsum and phosphogypsum

4.5. Cements and concretes

4.5.1. Portland cements and concretes

4.5.2. Alkali-activated cements and concretes. Geopolymers

5. Final remarks

Acknowledgements

References

\section{INTRODUCTION}

'Sustainable construction' and 'circular economy' are topical concerns directly relevant to the Sustainable Development Goals (SDGs) defined by the UN in 2015 and set out in Agenda 2030 (1-3) These SDGs looking for the peace and prosperity for people and the planet, now and into the future; among them is (Goal 11) "Make cities inclusive, safe, resilient and sustainable". The ultimate aim is to build a more sustainable world able to meet the needs of today's population without compromising those of tomorrow's.

One of the scientifically and technologically viable means of reaching the construction industry's sustainability targets is to reuse or valorise industrial waste/by-products (of widely differing origin and composition) to manufacture building materials, primarily cements and concretes and to added to achive to achive the low-carbon economy in Europe, (4). Such waste/by-products can be used to partially or wholly replace the main components of such materials (5-7). Their use may mitigate the adverse environmental impact inherent in the energy consumption, use of vast quantities of natural resources and water and emission of greenhouse gases associated with cement and concrete manufacture (8).

Deploying industrial waste/by-products as alternative materials in building material manufacture has become standard practice (9). Nonetheless, all necessary precautions must be taken to ensure that the inclusion and use of such materials entail no new health hazard for people or their environment. During their generation industrial waste/by-products may be contaminated with heavy metals or other undesirable chemicals or acquire high levels of natural radioactivity, which may adversely condition their deployment as alternative or secondary materials. In-depth and realistic study of such industrial waste is consequently requisite to their use in building materials $(1,10,11)$.

This paper focuses on the state of the art of the naturally occurring radioactive (NORM) waste/byproducts that can be used in cement and concrete design and manufacture. Natural radioactivity is present not only in industrial waste and by-products, but also in natural materials such as granite. Updated data on the use of aggregates in mortar and concrete manufacture are therefore likewise discussed in this review. A separate section is included on the current understanding of the radiological behaviour of alternative cements and concretes such as alkaliactivated systems or geopolymers, which may bear NORM waste as basic raw materials (precursor and alkaline activator). The article concludes with a series of recommendations on the preparation and use of cements and concretes containing naturally occurring radioactive materials.

\section{RADIOACTIVITY AND NATURAL RADIOACTIVITY: THE BASICS}

\subsection{Types of radioactivity}

Radioactivity is the result of spontaneous nuclide decay with the emission of radiation, i.e., $\alpha$ and $\beta$ particles together normally in conjunction with electromagnetic waves in the form of $\gamma$-radiation and $\mathrm{X}$-rays (12). In the International System the unit used to express radionuclide activity is the becquerel (Bq), equal to the activity of a quantity of a radionuclide spontaneously decaying at a rate of one nuclear transition per second. During decay, the socalled parent nuclide transitions to a different type of nucleus, known as the daughter, which may be a different chemical element or an isotope, depending on the type of decay. The energy emitted, either directly $(\alpha-$ or $\beta$-radiation) or indirectly ( $\gamma$-radiation or X-rays) suffices to strip electrons off and thus ionising any atom in the path of radiation (12). A brief description of the above four types of radiation follows.

Alpha $(\alpha)$ radiation consists in $\alpha$-particles containing 2 protons and 2 neutrons: i.e., it is identical to the nucleus of the He atom. Alpha particles are characterised by a relatively large mass and a positive elementary electrical charge of 2, an indication of low penetrating power. In biological tissues its path is no longer than a few tens of micrometres. Alpha radiation is ionising, generating more ions per unit 
length in the host matter than other types of radiation because the particles shed all their energy over a short distance. Alpha emitters induce primarily internal exposure via inhalation, ingestion or contact with the skin (12).

Beta $(\beta)$ radiation comprises $\beta$-particles, either electrons with a negative elementary charge or, less commonly, positrons or particles with a positive elementary electrical charge equal to the electron's negative charge. As an electron's mass is about 8000 times smaller than $\alpha$-particle mass, $\beta$-radiation has moderate penetrating power. Exposure to beta particles is more of an external and less of an internal radiation hazard than exposure to alpha particles. The external radiation attributable to beta particles is confined primarily to the epidermis or outer layers of skin, although it may also be harmful to the crystalline lens of the eye.

Gamma $(\gamma)$ radiation consists in high-energy photons (electromagnetic waves) emitted by the nucleus. This type of radiation is only weakly ionising but has high penetrating power and can travel across hundreds of meters of air. Thick concrete or lead shielding is normally used as protection against $\gamma$ radiation, exposure to which primarily affects external body parts. Given the high penetrating power of gamma rays, the energy released in internal exposure is absorbed by a smaller volume of tissue than is impacted by alpha or beta radiation. Internal exposure to gamma radiation is therefore less of a health hazard than similar exposure to alpha or beta radiation.

X-rays are electromagnetic waves emitted from the atomic shell, normally carrying lower energy than $\gamma$-radiation.

Radiation can be classified from two perspectives: whether or not it is ionising and whether natural or artificial. Ionising radiation is electromagnetic or corpuscular. When interacting with matter it ionises its atoms, modifying the atomic structure of the host material and inducing chemical reactions. Non-ionising radiation, which lacks that capacity, generates electromagnetic fields and optical radiation (13).

Natural radiation is the radiation present in the air, the Earth's crust, outer space, foodstuffs and even inside animal and human bodies. Artificial radiation is generated by human activity, such as in the wake of nuclear explosions or accidents, industrial activity or medical testing. All exist in the environment and impact human beings and all other species. Humans receive both natural and artificial radiation in the mean yearly proportions illustrated in Figure 1.

\subsection{Naturally occurring radioactive materials (NORM). NORM industries}

As the name infers, naturally occurring radioactive materials (NORM) are radioactive materials

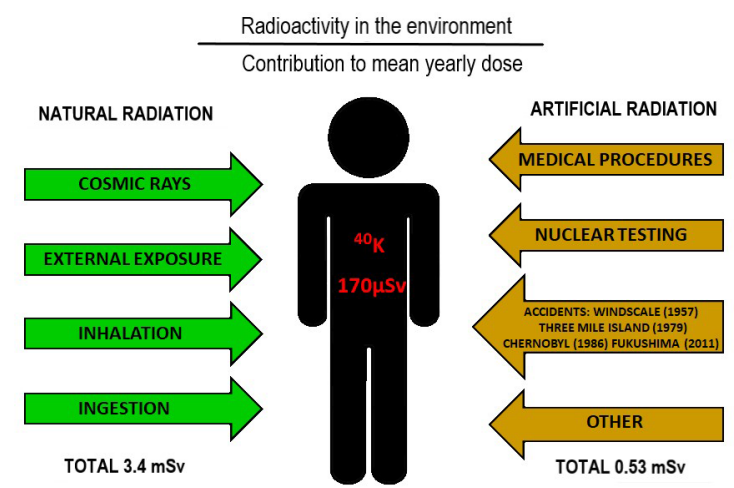

FIGURE 1. Distribution of mean yearly dose of natural and artificial radiation in human beings.

of natural origin whose potential as a hazard in their unaltered state may be enhanced by human technological manipulation. Pastor et al. (14) define NORM waste (in Spain) as material for which the generator envisages no use and which exhibits a natural nuclide concentration higher than stipulated for exemption and clearence "exemption and clearanceas per Spanish Ministry of Industry, Energy and Tourism (IET) order 1946/2013 (15) (Table 1) (14). Such waste must therefore be managed bearing in mind both its nature as industrial residue and the characteristics intrinsic to NORM materials.

TABLE 1. Ceilings (in $\mathrm{Bq} / \mathrm{g}$ ) for NORM waste to qualify for exemption and clearance (14).

\begin{tabular}{ccc}
\hline Radionuclide & All materials & Oil and gas sludges \\
\hline U-238 (Sec.) incl. U-235 (Sec.) & 0.5 & 5 \\
U natural & 5 & 100 \\
Th-230 & 10 & 100 \\
Ra-226+ & 0.5 & 5 \\
Pb-210+ & 5 & 100 \\
Po-210 & 5 & 100 \\
U-235 (sec) & 1 & 10 \\
U-235+ & 5 & 50 \\
Pa-231 & 5 & 50 \\
Ac-227+ & 1 & 10 \\
Th-232 (sec) & 0.5 & 5 \\
Th-232 & 5 & 100 \\
Ra-228+ & 1 & 10 \\
Th-228+ & 0.5 & 5 \\
K-40 & 5 & 100 \\
\hline
\end{tabular}

[Sec.: radionuclide in secular equilibrium with all its progeny; +: radionuclide in secular equilibrium with all its short-lived progeny] 
NORM waste may be generated by a number of industries, and most significantly those listed in Table 2 (14). Its management, the responsibility of the generators, entails determining the most suitable type of processing based on its radiological characterisation.

TABLE 2. NORM waste-generating industries (14).

\begin{tabular}{l}
\hline \multicolumn{1}{c}{ Industry } \\
\hline Rare earth mining \\
Rare earth extraction from monazite \\
Thorium and thorium compound manufacture and use \\
Niobium and ferro niobium production \\
Niobium/tantalum ore processing \\
Gas and oil production \\
Cement production, clinker kiln maintenance \\
Titanium dioxide (TiO ${ }_{2}$ ) pigment manufacture \\
Phosphate industry (phosphoric acid and phosphate fertiliser \\
production) \\
Zircon and zirconium industry \\
Tin, copper, aluminium, iron, steel, zinc and lead production \\
Coal-fired steam power plants, boiler maintenance \\
Geothermal energy production \\
Non-uranium mineral mining \\
Underground water filtering facilities
\end{tabular}

Granite is a naturally radioactive material used in building or as a component in concretes. It has a high activity concentration of certain natural radioactive series, including uranium, thorium, actinium and potassium (16-18). A recent study conducted by the present authors (19) showed that granite aggregate particle size distribution affects activity concentration, with smaller particle sizes inducing higher activity. This matter is discussed in greater depth in a subsequent section.

\section{NORM WASTE USED IN CEMENT AND CONCRETE PRODUCTION}

A wide variety of waste types and other materials with natural radioactivity can be used in cement and concrete manufacture. Some, such as coal-fired steam power plant fly ash and blast furnace slag, have been in use for decades. Fairly recent evidence of radioactive emissions from those materials, however, necessitates acquiring an understanding of and as far as possible controlling such radioactivity. Those two materials are described in detail in (10) and (20).

The use of industrial waste/by-products in Portland clinker and cement manufacture is closely related to sustainability and sustainable construction.
It has become a standard practice progressively applied to all the processes involved in producing those building materials: from the total or partial replacement of the natural materials and fuel used in raw mixes to the inclusion of active additions (supplementary cementitious materials, SCMs). Such residue is even deployed in the development of new alternative cements or new formulations, such as alkali-activated materials (also called geopolymers). Moreover, of the 27 types of ordinary cement listed in European standard EN 197-1: 2011 (21), 26 contain some manner of supplementary cementitious materials (SCMs) which may be industrial waste/byproducts such as siliceous or calcareous fly ash, blast furnace slag or silica fume (Table 3).

The partial replacement of the standard raw materials (essentially limestone and clay) in Portland raw mixes with industrial waste/by-products to manufacture Portland cement clinker is an area of scientific and technological research routinely conducted on site at clinker and cement plants. Such replacement lowers greenhouse gas emissions (primarily $\mathrm{CO}_{2}$ ) as well as the need for raw material (mainly limestone) quarrying. Some of that waste, including crystallised blast furnace slag (22), by-products of fired clay product manufacture (23) or waste generated in aluminium recycling (24), may constitute NORMs. The use of other kinds of waste (such as meat meal or crushed tyre ash, used solvents and oils) as partial substitutes for fossil fuels (primarily gas-oil) in cement kilns has likewise been studied (25).

In other words, Portland cement is directly related to the use of industrial waste/by-products, many of which may exhibit some natural radiation that must be understood, determined and controlled. Of particular interest in that regard are cements that serve as alternatives to OPC such as alkali-activated cements (also called geopolymers). The two essential components in those materials are a precursor (with a chemical composition defined in the $\mathrm{CaO}-\mathrm{SiO}_{2}-$ $\mathrm{Al}_{2} \mathrm{O}_{3}$ ) system) (26-30) and a solid or liquid alkaline activator. The latter is used to ensure a highly alkaline $(\mathrm{pH}>13)$ medium to dissolve the precursor and induce the condensation, coagulation and precipitation of layered and/or three-dimensional, highly compacted, high-strength reaction products. In such systems, both precursor and activator may consist in industrial waste/by-products (30-35). The precursors may be thermally and alkali-activated clays (such as metakaolin) (36), although in most alkaline cements (or geopolymers) practically $100 \%$ of the precursor is an industrial waste/by-product. The ones most widely used are vitreous or glassy blast furnace slag and aluminosilicate fly ash (ASTM type F) or a combination of the two (37). Other precursors may also be deployed, including rice husk ash (34), waste glass (38), urban solid, including construction and demolition, waste (39), spent FCC catalysts (40) and ceramic industry waste (41). The alkaline activators 
TABLE 3. The 27 products in the family common cements EN 197-1:2011.

\begin{tabular}{|c|c|c|c|c|c|c|c|c|c|c|c|c|c|}
\hline \multirow{5}{*}{$\begin{array}{l}\text { Main } \\
\text { Types }\end{array}$} & \multirow{5}{*}{$\begin{array}{l}\text { Notation of the } \\
\text { (types of comm }\end{array}$} & & \multicolumn{11}{|c|}{ Composition (percentage by mass ${ }^{a}$ ) } \\
\hline & & & \multicolumn{10}{|c|}{ Main constituents } & \multirow{4}{*}{$\begin{array}{c}\text { Minor } \\
\text { additional } \\
\text { constituents }\end{array}$} \\
\hline & & $\begin{array}{l}27 \text { products } \\
\text { non cement) }\end{array}$ & \multirow{3}{*}{$\begin{array}{c}\text { Clinker } \\
\\
\text { K } \\
\end{array}$} & \multirow{3}{*}{$\begin{array}{c}\begin{array}{c}\text { Blastfurnace } \\
\text { slag }\end{array} \\
\\
\mathrm{S} \\
\end{array}$} & \multirow{3}{*}{$\begin{array}{c}\begin{array}{l}\text { Silica } \\
\text { fume }\end{array} \\
\\
D^{\mathbf{b}} \\
\end{array}$} & \multicolumn{2}{|c|}{ Pozzolana } & \multicolumn{2}{|c|}{ Fly ash } & \multirow{3}{*}{$\begin{array}{c}\begin{array}{c}\text { Burnt } \\
\text { shale }\end{array} \\
T \\
T\end{array}$} & \multicolumn{2}{|c|}{ Limestone } & \\
\hline & & & & & & \multirow{2}{*}{$\begin{array}{c}\text { natural } \\
\mathbf{P}\end{array}$} & \multirow{2}{*}{$\begin{array}{c}\begin{array}{c}\text { natural } \\
\text { calcined }\end{array} \\
\mathbf{Q}\end{array}$} & \multirow{2}{*}{$\frac{\text { siliceous }}{\mathrm{V}}$} & & & & & \\
\hline & & & & & & & & & $\mathbf{W}$ & & $\mathbf{L}$ & $\mathbf{L L}$ & \\
\hline CEM I & Portland cement & CEM I & $95-100$ & - & - & - & - & - & - & - & - & - & $0-5$ \\
\hline \multirow[t]{19}{*}{ CEM II } & \multirow{2}{*}{$\begin{array}{l}\text { Portland-slag } \\
\text { cement }\end{array}$} & CEM II/A-S & $80-94$ & $6-20$ & - & - & - & - & - & - & - & - & $0-5$ \\
\hline & & CEM II/B-S & $65-79$ & $21-35$ & - & - & - & - & - & - & - & - & $0-5$ \\
\hline & $\begin{array}{l}\text { Portland-silica } \\
\text { fume cement }\end{array}$ & CEM II/A-D & $90-94$ & - & $6-10$ & - & - & - & - & - & - & - & $0-5$ \\
\hline & \multirow{4}{*}{$\begin{array}{l}\text { Portland- } \\
\text { pozzolana } \\
\text { cement }\end{array}$} & CEM II/A-P & $80-94$ & - & - & $6-20$ & - & - & - & - & - & - & $0-5$ \\
\hline & & CEM II/B-P & $65-79$ & - & - & $21-35$ & - & - & - & - & - & - & $0-5$ \\
\hline & & CEM II/A-Q & $80-94$ & - & - & - & $6-20$ & - & - & - & - & - & $0-5$ \\
\hline & & CEM II/B-Q & $65-79$ & - & - & - & $21-35$ & - & - & - & - & - & $0-5$ \\
\hline & \multirow{4}{*}{$\begin{array}{l}\text { Portland-fly ash } \\
\text { cement }\end{array}$} & CEM II/A-V & $80-94$ & - & - & - & - & $6-20$ & - & - & - & - & $0-5$ \\
\hline & & CEM II/B-V & $65-79$ & - & - & - & - & $21-35$ & - & - & - & - & $0-5$ \\
\hline & & CEM II/A-W & $80-94$ & - & - & - & - & - & $6-20$ & - & - & - & $0-5$ \\
\hline & & CEM II/B-W & $65-79$ & - & - & - & - & - & $21-35$ & - & - & - & $0-5$ \\
\hline & \multirow{2}{*}{$\begin{array}{l}\text { Portland-burnt } \\
\text { shale cement }\end{array}$} & CEM II/A-T & $80-94$ & - & - & - & - & - & - & $6-20$ & - & - & $0-5$ \\
\hline & & CEM II/B-T & $65-79$ & - & - & - & - & - & - & $21-35$ & - & - & $0-5$ \\
\hline & \multirow{4}{*}{$\begin{array}{l}\text { Portland } \\
\text { limestone cement }\end{array}$} & CEM II/A-L & $80-94$ & - & - & - & - & - & - & - & $6-20$ & - & $0-5$ \\
\hline & & CEM II/B-L & $65-79$ & - & - & - & - & - & - & - & $21-35$ & - & $0-5$ \\
\hline & & CEM II/A-LL & $80-94$ & - & - & - & - & - & - & - & - & $6-20$ & $0-5$ \\
\hline & & CEM II/B-LL & $65-79$ & - & - & - & - & - & - & - & - & $21-35$ & $0-5$ \\
\hline & \multirow{2}{*}{$\begin{array}{l}\text { Portland- } \\
\text { composite }^{\text {cement }^{c}}\end{array}$} & CEM II/A-M & $80-94$ & <----------- & ---- & ---- & ------ & -20------ & ---- & - & - & $>$ & $0-5$ \\
\hline & & CEM II/B-M & $65-79$ & $<--------$ & -- & -- & ------ & -35---- & - & 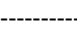 & . & & $0-5$ \\
\hline \multirow[t]{3}{*}{ CEM III } & \multirow{3}{*}{$\begin{array}{l}\text { Blastfurnace } \\
\text { cement }\end{array}$} & CEM III/A & $35-64$ & $36-65$ & - & - & - & - & - & - & - & - & $0-5$ \\
\hline & & CEM III/B & $20-34$ & $66-80$ & - & - & - & - & - & - & & & $0-5$ \\
\hline & & CEM III/C & $5-19$ & $81-95$ & - & - & - & - & - & - & & & $0-5$ \\
\hline \multirow[t]{2}{*}{ CEM IV } & Pozzolanic & CEM IV/A & $65-89$ & - & $<------$ & ------------. & $----11-35$ & -----------. & -------> & - & & & $0-5$ \\
\hline & & CEM IV/B & $45-64$ & - & $<-----$ & - & -----6-55- & ---------- & ----------->> & - & & & $0-5$ \\
\hline CEM V & Composite & CEM V/A & $40-64$ & $18-30$ & - & $<-------18$ & -30------>> & - & - & - & & & $0-5$ \\
\hline & cemen & CEM V/B & $20-38$ & $31-50$ & - & $<-------3$ & -50------>> & - & - & - & & & $0-5$ \\
\hline
\end{tabular}

${ }^{\mathrm{a}}$ The values in the table refer to the sum of the main and minor additional constituents

${ }^{\mathrm{b}}$ The proportion of silica fume is limited to $10 \%$

'In Portland-composite cements CEM II/A-M and CEM II/B-M, in pozzolanic cements CEM IV/A and CEM IV/B and in composite cements CEM V/A and CEM V/B the main constituents other than clinker shall be declared by designation of the cement(for example see clause 8 )

conventionally used, $\mathrm{NaOH}, \mathrm{KOH}$ and waterglass, may in turn be replaced by waste materials such as waste glass waste $(32,33,42)$ or biomass ash $(43,44)$, which have proven to be highly effective alkaline activators.

Industrial waste/by-products (fly ash, silica fume) may also be used in concrete manufacture. In addition to construction and demolition waste (CDW), which plays a well-known role as a source of recycled aggregates (45-47), natural products may also be used: granite, for instance, is of particular relevance to the present context in light of its high radon radioactive content and emissions. Organic and inorganic admixtures (natural or artificial pigments) are also widely used in concrete manufacture. Some natural pigments may also have a high radioactive (48).
Further to the foregoing, many types of industrial waste/by-products carrying natural radioactivity are or may be used in cement and concrete manufacture. By way of summary, NORMs (natural and waste products that can be used to manufacture these construction materials) may include any of the following (10).

a. NORMs in waste materials

- coal fly ash

- iron and steel mill slag

- phosphorus slag

- tin and copper slag

- phosphogypsum

- aluminium processing waste (red mud)

b. NORMs in natural materials

- alum shale 
- Igneous building materials or additives of natural origin: granitoids (granite, syenite, orthogneiss), porphyries, tuff, pozzolana (pozzolanic ash) and lava.

\section{RADIOLOGICAL BEHAVIOUR IN NORM WASTE, CEMENTS AND CONCRETES}

Building materials may exhibit a variable radionuclide content, in particular ${ }^{226} \mathrm{Ra}$ (uranium series), ${ }^{232} \mathrm{Th}$ (thorium series) and ${ }^{40} \mathrm{~K}$. Those three elements are used to determine the activity concentration in$\operatorname{dex}(\mathrm{ACI})$, calculated as per Equation [1]:

$$
A C I=\frac{C_{226} 6_{R a}}{300}+\frac{C_{232} T h}{200}+\frac{C_{40} K}{3000} \leq 1
$$

where $\mathrm{C}$ is the activity concentration in $\mathrm{Bq} \cdot \mathrm{kg}^{-1}$ of the respective radionuclides. In building materials $\mathrm{C}$ may vary from $1 \mathrm{~Bq} \mathrm{~kg}^{-1}$ to $4000 \mathrm{~Bq} \mathrm{~kg}^{-1}(49,50)$.

EU Directive 2013/59/Euratom (51) is the most recent European legislation on protection from ionising radiation. Its Article 75 stipulates that the reference level for indoor external exposure to gamma radiation emitted by building materials, in addition to outdoor external exposure, is $1 \mathrm{mSv} /$ year. That value is determined using radionuclide activity concentration as set out in Equation [1]. The index relates to the gamma radiation dose in excess of typical outdoor exposure in a building constructed from a specified building material. It applies to the building material, not its constituents, except when those constituents are building materials themselves and are separately assessed as such. For application of the index to such constituents, in particular residues from industries processing naturally-occurring radioactive material recycled into building materials, an appropriate partitioning factor needs to be applied. The activity concentration index value of 1 can be used as a conservative screening tool for identifying materials that may cause the reference level laid down in Article 75 (1) to be exceeded. Dose calculation must also take other factors into account, such as material density, thickness and intended use (bulk or superficial) and type of building.

${ }^{226} \mathrm{Ra},{ }^{232} \mathrm{Th}$ and ${ }^{40} \mathrm{~K}$ concentration and the activity of their progeny or others that may be of relevance to determine radioactivity in these building materials is determined with gamma spectrometry. For a detailed description of the methodology and conditions for determining the presence of such isotopes, see $(52,53)$.

The following is a discussion of the radiological behaviour of the industrial by-products or supplementary cementitious materials (SCMs) most widely used in cements and concretes and the radiological behaviour of the end products bearing such waste.

\subsection{Coal-fired power plant fly ash and botton ash}

Coal fly ash (FA) is a fine powder generated when coal is burnt to produce electricity, usually in coalfired power plants. It consists primarily in non-combustible inorganic material but also contains some residual carbon sourced from partially non-combusted coal (54). Although fly ash particles are largely spherical, irregular or angular quartz or other grains are likewise often present in the ash. Coal fly ash is divided into two main groups: siliceous (V) and calcareous (W) in European legistation and Class C Fly Ashes in accordance with ASTM standard. V-type fly ash is pozzolanic whilst W-type ash generally exhibits hydraulic properties (21). V-type ash must have a reactive $\mathrm{CaO}$ content of less than and $\mathrm{W}$-type greater than $10 \%$.

Both siliceous (type $\mathrm{V}$ in European legislation and type F further to ASTM) and calcareous (W) ash are used to manufacture CEM II ordinary Portland cement, CEM II composite portland cement, CEM IV pozzolanic cement and CEM V composite cement. Further to the data in Table 3, the proportion of fly ash in the 10 cement types defined in EN 197-1: 2011 (with these fly ashes): ranges from $6 \%$ to $55 \%$ and more specifically for CEM II/A-V from $6 \%$ to $20 \%$; CEM II/B-V, $21 \%$ to $35 \%$; CEM IV/A $11 \%$ to $35 \%$; CEM IV/B $36 \%$ to $55 \%$; CEM V/A $18 \%$ to $30 \%$ and CEM V/B $31 \%$ to $49 \%$.

Siliceous fly ash with a low reactive $\mathrm{CaO}$ content is the type most widely used in cements and concretes. Due to ash pozzolanicity, early age mechanical strength is low in cements bearing a high content of the addition. The use of siliceous fly ash-additioned cements to manufacture concrete is nonetheless known to have beneficial effects, such as improved workability and significantly lower later age capillary porosity than the unadditioned material. That in turn induces higher mechanical strength and enhanced resistance to chlorides, sulfates and potential alkali-aggregate reactions (55).

The natural radioactivity of fly ash depends on the geological age of the original coal bed, the combustion process used and ash particle size; being of interest due to the accumulation of radioactivity - polonium 210 - in the smallest particles of fly ashes $(20,56,57)$. US Geological Surveys show that coal containing phosphate minerals such as monazite or apatite have high radioactive ${ }^{232} \mathrm{Th}$ concentrations, whereas coal containing both organic matter and mineral fractions have high levels of the ${ }^{238} \mathrm{U}$ radioactive series (58). The respective radionuclides are retained during coal combustion and concentrate in the fly and bottom ash, more profusely in the former. Uranium and thorium concentrations may be up to ten-fold higher in bottom and fly ash than 
in burnt coal, while fly ash may contain even higher ${ }^{210} \mathrm{~Pb}$ and ${ }^{40} \mathrm{~K}$ concentrations. In modern power stations around $99 \%$ of the fly ash generated is typically retained (90\% in some older plants) (59). The finest ash particles have been observed to bear ${ }^{210} \mathrm{~Pb}$ contamination. Higher concentrations of that isotope are found in fly than in bottom ash because lead volatises in the combustion chamber $(60,61)$. ${ }^{226} \mathrm{Ra}$ contamination has also been detected in the finer fractions, where the ${ }^{210} \mathrm{~Pb} /{ }^{226} \mathrm{Ra}$ ratio may exceed 3 compared to no more than 0.5 in bottom ash (20).

Detailed information on the radionuclides in fly ash can be found in (20) and $(62,63,64)$. The uranium series $\left({ }^{226} \mathrm{Ra}\right.$ and $\left.{ }^{232} \mathrm{Th}\right)$ and ${ }^{40} \mathrm{~K}$ concentrations (in $\mathrm{Bq} \mathrm{kg}^{-1}$ ) in several European countries graphed in Figure 2 vary widely and depend, as noted earlier, on the original coal, combustion process and ash particle size. Table 4 gives the concentration ranges for radionuclides in fly ash sourced from a series of widely differing coal-fired steam power plants. The data show that coal fly ash has a high radionuclide content and the highest radioactivity of all the SCMs listed in standard EN 191-1: 2011. Further to Directive 2013/59/EURATOM (51), ACI values (Equation [1]) should be calculated only for endproducts, not for their constituents such as fly ash. Nonetheless, based on its radionuclide concentration (Table 4), the ACI for that by-product would be on the order of 0.5 to $1.5(65)$.

\subsection{Iron and steel mill slag}

The iron and steel industry generates different types of by-products, most prominently blast furnace (iron) and steel (steel) mill slag. The former, when vitreous and finely ground, exhibits hydraulicity and hence is widely used in cement and concrete manufacture $(76,77)$. The latter is less frequent in construction in light of its high heavy metal content and radioactivity, along with its unbound $\mathrm{CaO}$ and $\mathrm{MgO}$ and dicalcium silicate $\left(2 \mathrm{CaO} \cdot \mathrm{SiO}_{2}\right.$ or $\left.\mathrm{C}_{2} \mathrm{~S}\right)$ contents that may pose expansion or soundness problems over time. Its poor physical properties (low polished

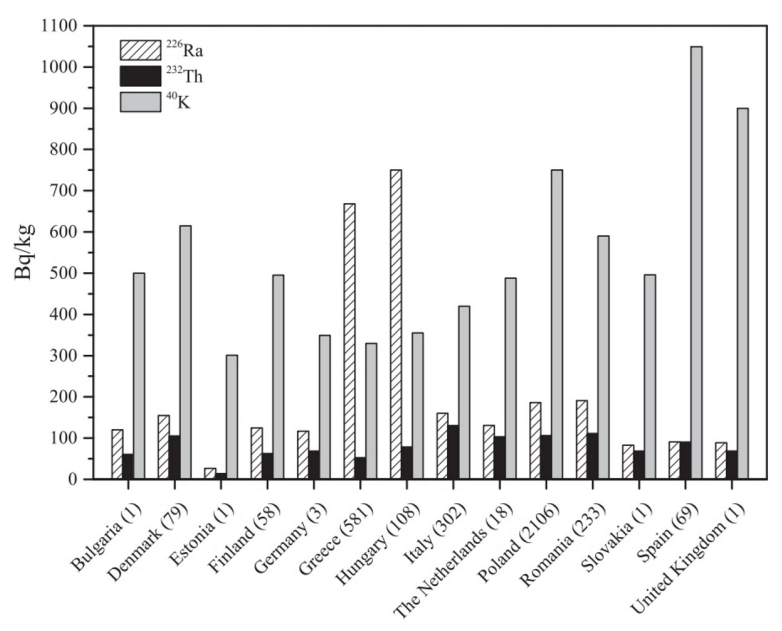

FIGURE 2. Natural radionuclide concentration in fly and bottom ash (62). In parentheses the number of samples analyzed. Reproduced with kind permission of Elsevier.

stone value, PSV, and high aggregate abrasion value, AAV) further condition its use $(22,78,79)$, which is restricted to non-structural works and road bases and sub-bases.

Blast furnace slag is the result of contact between the clay-like acid gangue from iron ore and the sulphur ash from (likewise acid) coke on the one hand and the lime and magnesium (both basic) from the more or less dolomitic limestone materials used as fluxes on the other. That combination of acid $\left(\mathrm{SiO}_{2}\right.$ and $\left.\mathrm{AI}_{2} \mathrm{O}_{3}\right)$ and basic $(\mathrm{CaO}$ and $\mathrm{MgO})$ oxides at high $\left(>1600{ }^{\circ} \mathrm{C}\right)$ temperatures yields slag. When the molten magma cools rapidly to ambient temperature via granulation or pelletising procedures, the resulting material is over $90 \%$ amorphous. Such glassy, ground (GBFS) blast furnace slag is hydraulic, meaning that when mixed with water it can harden like cement (76). If it cools slowly, however, the result is a highly crystalline (crystallised slag), low reactivity material that can be included as a raw material in portland cement raw mixes (80) or used as a filler in road bases and sub-bases (81). The majority chemical components of blast furnace

TABLE 4. Radionuclide concentration ranges in supplementary cementitious materials used in cement and concrete manufacture (Bq $\left.\mathrm{kg}^{-1}\right)$.

\begin{tabular}{|c|c|c|c|c|}
\hline \multirow{2}{*}{ Material } & \multicolumn{3}{|c|}{ Radionuclide concentration $\left(\mathrm{Bq} \mathrm{kg} \mathbf{~ k g}^{-1}\right)$} & \multirow[b]{2}{*}{ References } \\
\hline & ${ }^{226} \mathbf{R a}^{*}$ & ${ }^{232} \mathbf{T h}^{\text {*** }}$ & ${ }^{40} \mathbf{K}$ & \\
\hline Coal fly ash & $70-250$ & $50-180$ & $100-600$ & $(20,62-75)$ \\
\hline Blast furnace slag & $35-160$ & $30-100$ & $75-250$ & $(20,59,62,64-66,70,82)$ \\
\hline Steel slag & 20 & 5 & 2 & $(66)$ \\
\hline Silica fume & $1-2$ & $0.5-1$ & $90-100$ & $(65,66)$ \\
\hline Natural pozzolan & $10-20$ & $20-25$ & $150-300$ & $(66)$ \\
\hline $\begin{array}{c}\text { Calcined natural } \\
\text { pozzolan (metakaolin) }\end{array}$ & $30-350$ & $20-30$ & $150-220$ & $(66,92)$ \\
\hline Limestone & $10-50$ & $1-30$ & $1-300$ & $(66,65,91,92)$ \\
\hline
\end{tabular}

* ${ }^{226} \mathrm{Ra}$ can be likened to ${ }^{214} \mathrm{~Pb}$ concentration

** ${ }^{232} \mathrm{Th}$ can be likened to ${ }^{212} \mathrm{~Pb}$ concentration 
slag include $\mathrm{SiO}_{2}(27-40 \%), \mathrm{CaO}(30-50 \%), \mathrm{Al}_{2} \mathrm{O}_{3}$ (5-25\%) and $\mathrm{MgO}(1-15 \%)$. Mellite, a solid solution containing gehlenite $\left(2 \mathrm{CaO} \cdot \mathrm{Al}_{2} \mathrm{O}_{3} \cdot \mathrm{SiO}_{2}\right)$ and akermanite $\left(2 \mathrm{CaO} \cdot \mathrm{MgO} \cdot 2 \mathrm{SiO}_{2}\right)$, is the majority phase in crystallised blast furnace slag. The chemical and mineralogical compositions of the two types of slag depend on the starting iron ore, the type of processing applied and the coke and fluxes used.

GBFS is an SCM used to manufacture ordinary CEM II/A-S and CEM/IIB-S cements, in which it accounts for $6 \%$ to $35 \%$ of the total weight; in cements CEM III/A, CEM III/B and CEM III/C the values are $36 \%$ to $95 \%$; and in cements CEM V/A and CEM V/B $18 \%$ to $50 \%$.

Steel slag, a by-product of steel manufacture, is formed in the reaction between fluxes such as calcium oxide and the non-metallic inorganic constituents of steel or scrap metal. Two types can be distinguished:

- Basic oxygen furnace (BOF) steel slag (10\% to $15 \% \mathrm{SiO}_{2} ; 45 \%$ to $60 \% \mathrm{CaO} ; 1 \%$ to $5 \%$ $\mathrm{Al}_{2} \mathrm{O}_{3} ; 3 \%$ to $9 \% \mathrm{Fe}_{2} \mathrm{O}_{3} ; 7 \%$ to $20 \% \mathrm{FeO} ; 3 \%$ to $13 \% \mathrm{MgO} ; 2 \%$ to $6 \% \mathrm{MnO}$; and $1 \%$ to $5 \%$ $\mathrm{P}_{2} \mathrm{O}_{5}$ ).

- Electric arc furnace (EAF) steel slag (11\% to $20 \% \mathrm{SiO}_{2} ; 30 \%$ to $50 \% \mathrm{CaO} ; 10 \%$ to $18 \%$ $\mathrm{Al}_{2} \mathrm{O}_{3} ; 5 \%$ to $6 \% \mathrm{Fe}_{2} \mathrm{O}_{3} ; 8 \%$ to $22 \% \mathrm{FeO} ; 8 \%$ to $13 \% \mathrm{MgO} ; 5 \%$ to $10 \% \mathrm{MnO} ; 2 \%$ to $5 \%$ $\mathrm{P}_{2} \mathrm{O}_{5}$ ).

The origin of iron and steel slag radioactivity lies in the iron ore and scrap metal used and the sintering processes deployed. Depending on the origin, iron ore may contain different radionuclides and heavy metals, with uranium concentration in the $20 \mathrm{~Bq} \mathrm{~kg}^{-1}$ to $30 \mathrm{~Bq} \mathrm{~kg}^{-1}$ range (81). In blast furnace slag, the source of natural radionuclide content has been confirmed to be not only the raw materials but the manufacturing process (type of furnace, for instance) (18). Figure 3 graphs the radionuclide concentrations in the iron and steel mill slag used in cement manufacture, whilst Table 4 gives the range of ${ }^{226} \mathrm{Ra}$ (uranium series), ${ }^{232} \mathrm{Th}$ (thorium series) and ${ }^{40} \mathrm{~K}$ concentrations in BFS and steel slag.

As the data in Figure 3 and Table 4 infer, blast furnace slag bears a much higher radionuclide content than steel slag, although the BFS values, with $\mathrm{ACI}$ generally $<1$, are lower than observed for coal fly ash (65).

\subsection{Other wastes and limestones used as supplementary cementitious materials (SCMs) in cement and concrete manufacture}

Table 3 shows that in addition to type $\mathrm{V}$ and $\mathrm{W}$ fly ash and vitreous slag (S), waste and materials, such as silica fume, limestone, natural pozzolans and

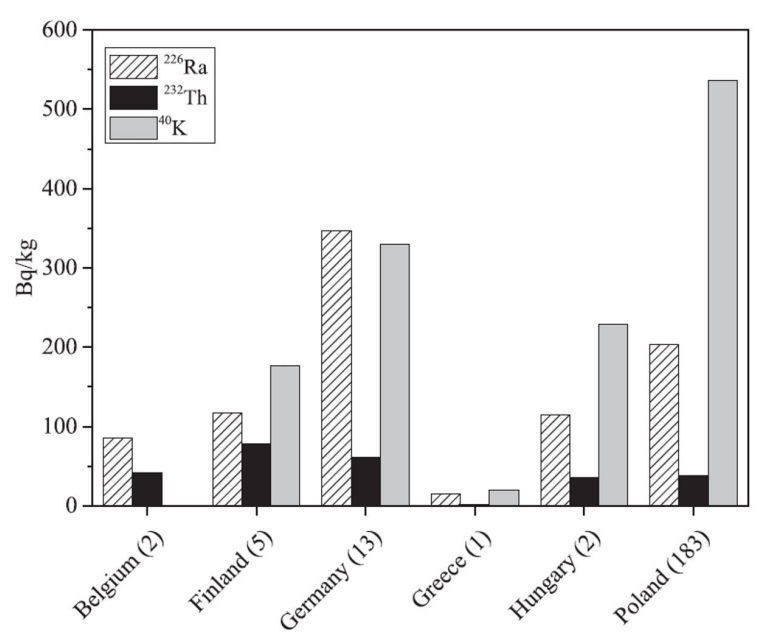

FIGURE 3. Radionuclide concentrations in blast furnace and steel mill slag used in building materials (62). In parentheses the number of samples analyzed. Reproduced with kind permission of Elsevier.

calcined shale are used as SCMs in the standardised ordinary cements listed in EN 197-1: 2011.

Silica fume (D) is a residue generated in electric arc furnaces producing silicon and ferro silicon metals. An inorganic product consisting in very fine spherical particles generated when coal reduces quartz, it is essentially ( $85 \%$ to $90 \%$ ) amorphous $\mathrm{SiO}_{2}$. With such a high amorphous $\mathrm{SiO}_{2}$ content and large specific surface (around $20000 \mathrm{~m}^{2} \cdot \mathrm{kg}^{-1}$ ), silica fume is highly pozzolanic. According to standard EN 197-1: 2011, CEM II/A-D cements may contain $6 \%$ to $10 \%$ silica fume. Blended Portland cements CEM II/A-M and CEM II/B-M as well as cements CEM IV/A and CEM IV/B may also bear up to $10 \%$ of that type of waste.

Portland cement with silica fume (CEM II/A-D) is apt for manufacturing of prestressed concrete, concrete with reactive aggregates and shotcrete or fast-setting concrete. Silica fume pozzolanicity determines the high reactivity and early age strength development in those materials (83). Silica fume can also be used as a cement replacement or addition to prepare very high-strength, durable concretes $(83$, 84 ), although it must not account for more than $5 \%$ to $10 \%$ of the total cement weight. The presence of this mineral addition in concrete has induced the development of so-called 'high performance' concretes. The large specific surface in silica fume determines the need for variable amounts of superplasticising admixtures in the respective concretes to lower the water/cement ratio while ensuring suitable rheology as well as the production of very high density, high performance and durable concretes (85).

The concentration ranges of ${ }^{226} \mathrm{Ra},{ }^{232} \mathrm{Th}$ and ${ }^{40} \mathrm{~K}$ (in $\mathrm{Bq} \mathrm{kg}^{-1}$ ) reported in the literature for silica fume (Table 4) are relatively low for the former two former and somewhat higher for ${ }^{40} \mathrm{~K}$. This SCM would not in any event appear to be a very significant 
source of natural radionuclides in the end cements and concretes.

Natural pozzolans are siliceous, alumino-siliceous (or a combination of the two) geological materials. The term was originally applied only to the volcanic tuff found in the area around Pozzoli, Italy, and used by the Romans to prepare hydraulic concretes. For several decades it has also been used, however, to designate natural materials able to react with the portlandite generated during the hydration at ambient temperature of the calcium silicates present in portland cement. The pozzolanic properties characterising the strong cohesive end products have determined the evolution of the term from its original geological meaning to its present technological connotations (86). Natural pozzolans, like aluminosiliceous fly ash and silica fume, exhibit the pozzolanic characteristics defined in standard EN 197-1: 2011, which describes two types of materials: natural pozzolans $(\mathrm{P})$ and naturally occurring fired pozzolana (Q). Natural pozzolans are normally volcanic materials or sedimentary rocks with the chemical and mineral compositions specified, whilst naturally occurring fired pozzolans are thermally activated volcanic, clay, slate or sedimentary rocks.

These materials can be used to manufacture cements CEM II/A-P and CEM II/B-P, CEM II/A-Q and $\mathrm{CEM}$ II/B-Q with $6 \%$ to $30 \%$ pozzolan by cement weight, as well as cements CEM IV/A and B and CEM V/A and B. Content is defined in keeping with availability. The characteristics of cements with natural pozzolans are qualitatively similar to but more intense than observed in materials with greater pozzolanicity such as silica fume and type $\mathrm{V}$ fly ash. P-type pozzolans are also apt for the manufacture of alternative materials such as alkaline cements (87).

The concentration ranges of ${ }^{226} \mathrm{Ra},{ }^{232} \mathrm{Th}$ and ${ }^{40} \mathrm{~K}$ (in $\mathrm{Bq} \mathrm{kg}^{-1}$ ) reported in the literature for natural and naturally occurring fired pozzolans used in cement manufacture are listed in Table 4, where metakaolin (MK) has been included as an example of the latter. Further to those data, the ${ }^{226} \mathrm{Ra}$ content may be higher and more variable in MK than in non-fired natural pozzolans.

Limestone (L and LL) is another material used as an addition in ordinary cements. It must also meet a series of chemical and physical requirements to be apt for ordinary cement manufacture. Its calcium carbonate content $\left(\mathrm{CaCO}_{3}\right)$, calculated of terms of calcium oxide $(\mathrm{CaO})$, must be at least $75 \mathrm{wt} \%$, the clay content must be lower than $1.20 \mathrm{~g} / 100$ and the total organic carbon (TOC) must not exceed $0.20 \mathrm{wt} \%$ in subtype LL or $0.50 \mathrm{wt} \%$ in subtype L (21).

Limestone is present in cements CEM II/A-L and B-L at $6 \%$ to $30 \%$ by cement weight and in the same proportions in cements CEM II/A-LL and CEM II/B-LL. Limestone has no pozzolanic or hydraulic properties, but neither is it a wholly inert addition as believed until not long ago. Its presence in cement induces a series of very distinct chemical and physical characteristics explained by such non-inertness. Its most prominent effects include improved paste workability, which lowers water demand; absence of any impact on early or late age strength when limestone content is under $10 \%$ by cement weight; and lesser expansion at all ages (88). In contrast, thaumasite formation-related durability issues have been described in cements with high limestone contents (89).

According to the concentration ranges of ${ }^{226} \mathrm{Ra}$, ${ }^{232} \mathrm{Th}$ and ${ }^{40} \mathrm{~K}$ (in $\mathrm{Bq} \mathrm{kg}^{-1}$ ) reported in the literature for limestone (Table 5), the material exhibits fairly low uranium and thorium series contents, but a much broader range of ${ }^{40} \mathrm{~K}$ activity concentrations.

Table 5 also gives the ${ }^{226} \mathrm{Ra},{ }^{232} \mathrm{Th}$ and ${ }^{40} \mathrm{~K}$ ranges (in $\mathrm{Bq} \mathrm{kg} \mathrm{kg}^{-1}$ ) for other industrial waste/by-products such as red mud, biomass ash and waste glass which, while not standardised, can be used as portland or alkali-activated (geopolymer) cement additions.

Red mud is waste generated in Bayer process-mediated bauxite refining, in which ground bauxite reacts with sodium hydroxide at high temperatures and pressures. A highly alkaline ( $\mathrm{pH} \sim 10$ to 12.5) slurry, it has a solids content of $15 \mathrm{wt} \%$ to $30 \mathrm{wt} \%$. Its composition features fine silica, aluminium, iron, calcium and titanium oxide particles in proportions that differ depending on the bauxite ore, conditions governing aluminium extraction and quality control (18). Its alkalinity, toxic element content and natural radioactivity (bauxite waste ACI is consistently over 1: Equation [1]) limit its use in construction (20).

TABLE 5. ${ }^{226} \mathrm{Ra},{ }^{232} \mathrm{Th}$ and ${ }^{40} \mathrm{~K}$ radionuclide concentration $\left(\mathrm{Bq} \mathrm{kg}^{-1}\right)$ in industrial waste/fly ash not cited in European standards that can be used in cement and concrete manufacture.

\begin{tabular}{|c|c|c|c|c|}
\hline \multirow{2}{*}{ Material } & \multicolumn{3}{|c|}{ Radionuclide concentration $\left(\mathrm{Bq} \cdot \mathrm{kg}^{-1}\right)$} & \multirow[b]{2}{*}{ References } \\
\hline & ${ }^{226} \mathbf{R a}^{*}$ & ${ }^{232} \mathbf{T h}^{* * *}$ & ${ }^{40} \mathbf{K}$ & \\
\hline Bauxite residue or red mud & $100-700$ & $200-1320$ & $30-360$ & $(20,62,93,94)$ \\
\hline Biomass ash & $10-12$ & $6-7$ & $6000-36000$ & $(66)$ \\
\hline Waste glass & $8-9$ & $6-7$ & 230 & $(65,66)$ \\
\hline
\end{tabular}


Burning plants, trees and seed waste sourced from a wide variety of species to produce electric power yields biomass ash, generally in the form of fly and bottom ash. The chemical, mineralogical and radiological composition of such ash is highly dependent on the material burnt and the process. Some types of plant ash, such as rice husk and bagasse, exhibit pozzolanicity and can be used in cement and concrete $(95,96)$ or alkaline cement manufacture (34). Others such as olive tree ash, however, are scantly applicable as SCMs. Some of the present authors recently assessed the viability of biomass ash as an alternative alkaline activator in geopolymer manufacture (43). The very high ${ }^{40} \mathrm{~K}$ content observed, with ACI values consistently $>1$, (Table 5), must not be overlooked when considering its use.

Other types of waste such as glass hold promise for possible application in cement and concrete manufacture either as aggregates $(97,98)$ or as precursors and/or activators in geopolymers $(32,33$, 38 ). These materials vary widely in terms of their composition, while sodium silicate-based glass is the most apt for use in geopolymers. Further to the radiological data in Table 5, this waste poses no natural radiation-related problems, for its uranium, thorium and potassium contents are all fairly low.

\subsection{Gypsum and phosphogypsum}

Gypsum and phosphogypsum have some similar characteristics but are conspicuously different chemically and radiologically. Gypsum, hydrated calcium sulfate $\left(\mathrm{CaSO}_{4} \cdot 2 \mathrm{H}_{2} \mathrm{O}\right)$, is blended with clinker and SCMs in Portland cement manufacture. The most prominent of its various purposes is to react with the $\mathrm{C}_{3} \mathrm{~A}\left(3 \mathrm{CaO} \cdot \mathrm{Al}_{2} \mathrm{O}_{3}\right)$ in the clinker and the water present in the early stages of cement hydration to form ettringite $\left(3 \mathrm{CaO} \cdot \mathrm{Al}_{2} \mathrm{O}_{3}\right)$ $\left.\left(\mathrm{SO}_{4}\right)_{3}(\mathrm{OH})_{12} \cdot 31 \mathrm{H}_{2} \mathrm{O}\right)$. That reaction constrains or impedes any direct reaction between $\mathrm{C}_{3} \mathrm{~A}$ and water, preventing flash setting by retarding some of the cement hydration reactions. Gypsum may also be found in calcium sulfate cement hemihydrate $\left(\mathrm{CaSO}_{4} \cdot 1 / 2 \mathrm{H}_{2} \mathrm{O}\right)$ and anhydrite (anhydrous calcium sulfate, $\mathrm{CaSO}_{4}$ ) or any combination of the two. Gypsum and anhydrite are present in nature and calcium sulfate may be generated as a by-product in certain industrial processes. The ceiling sulfate content in ordinary cements, expressed as $\% \mathrm{SO}_{3}$, is $3.5 \%$ (in 32.5 and $42.5 \mathrm{~N}$ cements) or $4.0 \%(42.5 \mathrm{R}$ and 52.5 cements (21).

Phosphogypsum (PG), a phosphate industry byproduct, is generated during the acid digestion of phosphate ore (20). The industry is known to be vital to the worldwide food supply, given the role of phosphate fertilisers in extensive farming. Phosphate minerals carry high contaminating contents of uranium, radium, polonium, thorium and lead isotopes.

The ${ }^{226} \mathrm{Ra},{ }^{232} \mathrm{Th}$ and ${ }^{40} \mathrm{~K}$ concentrations (in $\mathrm{Bq} \mathrm{kg}{ }^{-1}$ ) for gypsum and phosphogypsum used in construction are given in Table 6 , which shows that as a rule the $\mathrm{U}$, Th and $\mathrm{K}$ series values are fairly low.

Approximately $70 \%$ of the phosphate ore mined is processed in an acid medium to produce phosphoric acid, during which procedure substantial quantities of phosphogypsum are generated. Depending on the raw ore used, PG may contain up to 60 times the radionuclide content found in the pre-processed rock (100). According to García-Díaz et al. (100) up to $80 \%$ of the ${ }^{226} \mathrm{Ra}$, up to $86 \%$ of the $\mathrm{U}$ and up to $70 \%$ of the Th may concentrate in PG. The radionuclide content in this material must be determined because ${ }^{226} \mathrm{Ra}$ generates radon gas $\left({ }^{222} \mathrm{Rn}\right)$, which with a short half-life of just $3.5 \mathrm{~d}$ is very active, i.e., emits intense radiation that may harm bodily organs.

This industrial by-product is scarcely used in construction due to its high radioactivity, although research has been ongoing for some time on its use in place of mineral gypsum and for other applications. A review of possible applications in building material production (101) cites setting control, mineralisation in clinker preparation and gypsum product manufacture as potential uses. A recent study (102) addresses the use of phosphogypsum instead of gypsum in super-sulfated cement-based concrete manufacture. As noted, its use is conditioned by its high radon radioactivity and emissions. A few studies and patents suggest that phosphogypsum can be purified by eliminating heavy metals and ${ }^{226} \mathrm{Ra}$ (104), while others (82) assess the use of alkaline cement matrices to immobilise the radon in phosphogypsum.

As the uranium, thorium and potassium concentrations in phosphogypsum of different origins graphed in Figure 4 show, the numbers vary widely. The ${ }^{226} \mathrm{Ra},{ }^{232} \mathrm{Th}$ and ${ }^{40} \mathrm{~K}$ concentrations $\left(\mathrm{Bq} \mathrm{kg}^{-1}\right)$ reported in the literature for this by-product and listed in Ta-

TABLE $6 .{ }^{226} \mathrm{Ra},{ }^{232} \mathrm{Th}$ and ${ }^{40} \mathrm{~K}$ concentration in gypsum $\left(\mathrm{Bq} \mathrm{kg}{ }^{-1}\right)$

\begin{tabular}{ccccc}
\hline \multirow{2}{*}{ Material } & \multicolumn{3}{c}{ Radionuclide concentration $\left(\mathbf{B q} \mathbf{~ k g}^{-1}\right)$} \\
\cline { 2 - 5 } & ${ }^{226} \mathbf{R a}^{*}$ & ${ }^{232} \mathbf{T h}^{* *}$ & ${ }^{40} \mathbf{K}$ & References \\
\hline Gypsum & $10-70$ & $5-100$ & $80-200$ & $(63,64,91,92,99)$ \\
Phosphogypsum & $35-1400$ & $20-160$ & $20-300$ & $(20,62,64,92,93,103)$ \\
\hline
\end{tabular}

* ${ }^{226} \mathrm{Ra}$ can be likened to ${ }^{214} \mathrm{~Pb}$ concentration

** ${ }^{232} \mathrm{Th}$ can be likened to ${ }^{212} \mathrm{~Pb}$ concentration 


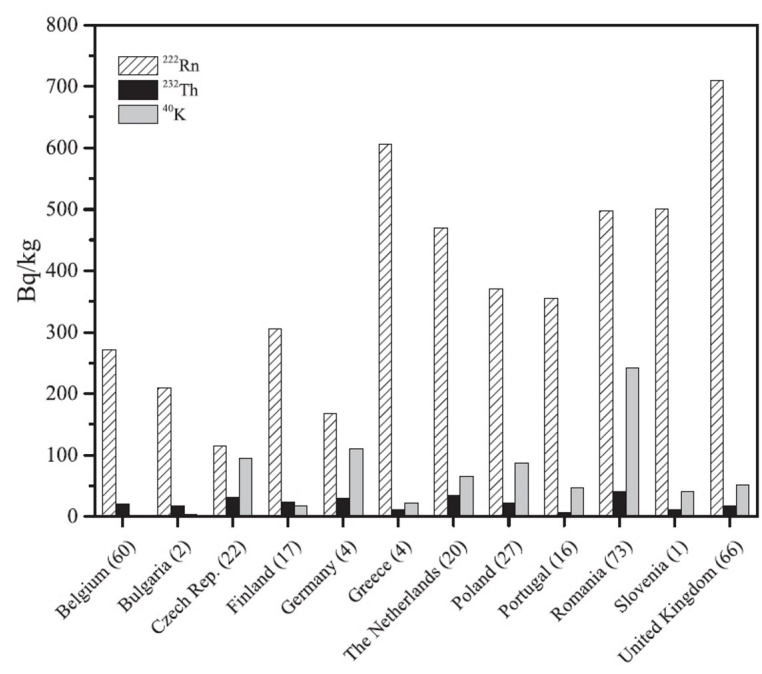

Figure 4. Natural radionuclide concentrations in the phosphogypsum present in building materials (62). In parentheses the number of samples analyzed. Reproduced with kind permission of Elsevier.

ble 6 also attest to enormous variability. The specific concentrations of naturally occurring radionuclides in phosphogypsum depend on the origin of the phosphate ore and the chemical process used (20). In wet phosphoric acid production, the amount of radionuclide taken up by each fraction may vary with the technology. As a rule most of the uranium ultimately remains in the fertiliser, whilst radium is more evenly distributed among the (by-)products, with some possibly precipitating in the plant. Most of the polonium is eliminated with the phosphogypsum fraction (103). With such variability the ACI values range from 0.5 to 4.0 , although most are $>1$ (20).

\subsection{Cements and Concretes}

This section draws a distinction between the more conventional cements and concretes based on portland or standardised materials and alternative cements and concretes (as a rule with a low or nil clinker content) such as alkali-activated products or geopolymers. The radiological behaviour of all these cements and concretes is described in great detail in a recent paper (8).

\subsubsection{Portland cements and concretes}

Nuccetelli et al. (62) studied the uranium, thorium and potassium series radionuclides in anhydrous portland cements in 21 European countries. Their findings, summarised in Table 7, revealed that radionuclide concentrations are fairly low, with ACI values ranging as a rule from 0.1 to 0.4 , far below the 2013/59/Euratom European Directive maximum of 1. Some authors (60) have reported higher ACI values for cements, however.

The presence of NORMs in industrial waste/byproducts such as coal-fired steam power plant fly ash or vitreous blast furnace slag may raise the natural radionuclide concentrations in ordinary cements, along with their ACI values. The radionuclide content in standardised commercial cements (66) is listed in Table 8 and in synthetically prepared anhydrous cements in Table 9 (65). The data denote an additive effect as well as proportionality between the radionuclide content and the percentage of 'pure' (unadditioned) cement and the SCM in each blend. Other authors report similar findings (70, 92, 105-107).

Table 8 also gives the radionuclide content in cements other than the ordinary materials listed in standard EN 197-1: 2011, including sulfate-resistant, white, calcium aluminate (CAC) and calcium sulfoaluminate cements. CACs exhibit the highest radionuclide concentration, particularly for thorium, with an ACI value of around 0.7 to 0.9 , much higher than the 0.2 to 0.4 recorded for unadditioned OPC. Neither the radionuclide concentrations nor the ACI values for the other cements analysed vary substantially from the findings for 'pure' Portland cement.

Studies of hydrated Portland cement paste radiological behaviour, i.e., their ${ }^{226} \mathrm{Ra}$, and ${ }^{40} \mathrm{~K}$ activity concentrations, have confirmed the dilution effect attributable to the mixing water, including the water that binds to the hydration products formed (65). Radionuclide activity concentrations are normally determined with gamma spectrometry on ground samples $(65,66)$. The concentrations in hydrated cement pastes bearing different types of SCMs are listed in Table 10. The dilution effect associated with water (water/cement ratio used in the mixes) on the radionuclide concentrations and the ACI for different pastes can be deduced from a comparison of the data in Table 10 to the values in Tables 8 and 9 .

The authors of this review recently proposed a new method for determining radionuclide concentration and ACI on hardened but unground Portland cement paste as part of Spanish Ministry of Science and Innovation-funded project BIA2016-77252-P. The method was developed on cubic specimens of $5 \mathrm{~cm}$ on a side of hardened and unadditioned Portland cement paste (52).

That new methodology was developed on $48 \mathrm{~h}$ and $64 \mathrm{~d}$ cubic ( $5 \mathrm{~cm}$ on side) specimens of hardened portland cement paste. The pastes were prepared with a number of gamma radiation 'cocktails' $\left({ }^{210} \mathrm{~Pb}\right.$, ${ }^{241} \mathrm{Am},{ }^{137} \mathrm{Cs},{ }^{60} \mathrm{Co},{ }^{40} \mathrm{~K}$ and ${ }^{226} \mathrm{Ra}$ ) with known activity concentrations and emission energy values ranging from $46.54 \mathrm{keV}$ to $1332.5 \mathrm{keV}$. The gamma cocktails were carefully blended with the water and cement to ensure a uniform mix. Gamma spectrometry was conducted on 48 hours and 64 days compact solid samples. The solid cubic specimens were measured at different heights on a LabSOCS-calibrated ultrapure germanium (HPGe) detector (52). The same pastes were ground and re-measured to validate the 


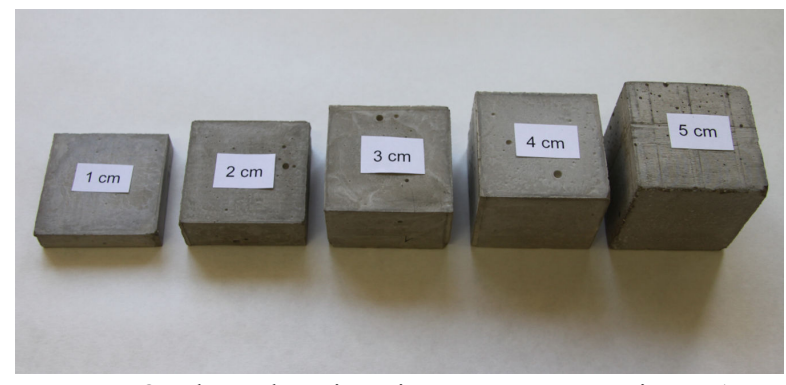

FIGURE 5. Quadrangular prismatic cement paste specimens $1 \mathrm{~cm}$ to $5 \mathrm{~cm}$ high (52). Reproduced with kind permission of Elsevier.

results for the cubic monolithic specimens $(5 \mathrm{~cm}$ on side). The specimens tested are depicted in Figure 5.

The findings showed that i) the experimentally tested activities found for both plastic cylindrical containers and cubic cement pastes using LabSOCScalculated efficiency proved to be statistically comparable, ii) the variation in efficiency with quadratic specimen height satisfactorily corrected the gamma photon attenuation induced by the photoelectric and Compton effects in the energy range studied (46.54 keV to $1332.5 \mathrm{keV}$ ) as well as changes in the solid angle of the detector, iii) as the activity found on the six sides of the cubic cement specimen were statistically indistinguishable, activity may be determined by measuring just one side and iv) the accuracy and precision observed for the two counting geometries met the standard acceptability criteria applied in environmental radioactivity laboratories. Although no significant differences were found between 48 hours and 64 days cubic cement paste activity, analyses should preferably be conducted after the hydration reactions have run full course to avoid possible distortions in the ${ }^{226} \mathrm{Ra}$ activity values calculated from ${ }^{222} \mathrm{Rn}$ progeny. Figure 6 graphs the variation in method efficiency with specimen height in the energy range studied. This new measuring methodology is currently being validated for cement pastes bearing NORM waste and hybrid alkali-activated cement pastes.

Radiological studies have likewise been conducted on Portland cement concretes (10). Trevisi et al. (105) ran an extensive study of the radiological data for a number of building materials, concretes among them. The concentration activities for concretes from different countries drawn from that paper are reproduced in Table 11 .

The value given for each concrete as a whole includes the radionuclide content in its main components: cement, water, aggregates, admixtures and mineral additions, all of which must be borne in mind in radiological assessments, given concrete heterogeneity.

The concentration activities of standardised and other conventional cements are tabled in earlier sections of this review. Aggregates, which account for $50 \%$ to $75 \%$ of the total weight, play a significant part in concrete properties and behaviour. Several authors have studied the radiological behaviour of different types of natural aggregates $(64,74,92,99,108)$.

TABLE 7. ${ }^{226} \mathrm{Ra},{ }^{232} \mathrm{Th}$ and ${ }^{40} \mathrm{~K}$ activity concentration in 2036 cement samples (62).

\begin{tabular}{|c|c|c|c|c|}
\hline Country (21 EU_MS) & No. of samples & ${ }^{226} \mathrm{Ra}\left(\mathrm{Bq} \mathrm{kg}{ }^{-1}\right)$ & ${ }^{232} \mathrm{Th}\left(\mathrm{Bq} \mathrm{kg}{ }^{-1}\right)$ & ${ }^{40} \mathrm{~K}\left(\mathrm{~Bq} \mathrm{~kg} \mathbf{~}^{-1}\right)$ \\
\hline Austria & 18 & 27 & 14 & 210 \\
\hline Belgium & 26 & 52 & 46 & 255 \\
\hline Bulgaria & 1 & 29 & 19 & 160 \\
\hline Cyprus & 20 & 23 & 8 & 136 \\
\hline Czech Republic & 496 & 46 & 19 & 237 \\
\hline Denmark & 6 & 20 & 12 & 90 \\
\hline Finland & 11 & 40 & 20 & 251 \\
\hline France & 1 & 35 & 21 & 24 \\
\hline Germany & 23 & 86 & 73 & 170 \\
\hline Greece & 183 & 85 & 19 & 257 \\
\hline Hungary & 400 & 30 & 22 & 218 \\
\hline Ireland & 3 & 60 & 11 & 131 \\
\hline Italy & 200 & 41 & 63 & 357 \\
\hline The Netherlands & 17 & 62 & 64 & 271 \\
\hline Poland & 344 & 73 & 66 & 353 \\
\hline Portugal & 8 & 31 & 19 & 256 \\
\hline Romania & 55 & 44 & 27 & 233 \\
\hline Slovakia & 6 & 35 & 18 & 223 \\
\hline Spain & 182 & 70 & 49 & 273 \\
\hline Sweden & 30 & 53 & 54 & 224 \\
\hline United Kingdom & 6 & 22 & 18 & 160 \\
\hline Overall average & & $46(22-86)$ & $32(8-73)$ & $214(24-357)$ \\
\hline
\end{tabular}


TABLE 8. Radionuclides in anhydrous commercial and standardised cements (66).

\begin{tabular}{|c|c|c|c|c|c|c|c|c|c|c|c|}
\hline \multirow{2}{*}{$\begin{array}{l}\text { Radioactive series } \\
\text { Anhydrous cement }\end{array}$} & \multicolumn{5}{|c|}{${ }^{238} \mathbf{U}$ (in $\left.\mathbf{B g ~ k g} \mathbf{~ g g}^{-1}\right)$} & \multirow{2}{*}{${ }^{235} \mathbf{U}$} & \multicolumn{3}{|c|}{${ }^{232} \mathbf{T h}$ (in Bg kg-1) } & \multirow{2}{*}{$\begin{array}{c}{ }^{40} \mathrm{~K} \\
\text { (in } \mathrm{Bg} \mathrm{kg}^{-1} \text { ) }\end{array}$} & \multirow[b]{2}{*}{ ACI } \\
\hline & ${ }^{234} \mathbf{T h}$ & ${ }^{226} \mathbf{R a}$ & ${ }^{214} \mathbf{P b}$ & ${ }^{214} \mathbf{B i}$ & ${ }^{210} \mathbf{P b}$ & & ${ }^{228} \mathrm{Ac}$ & ${ }^{212} \mathbf{P b}$ & ${ }^{208} \mathrm{Tl}$ & & \\
\hline CEM I $52,5 \mathrm{R}$ & $17.6 \pm 2.3$ & $17.1 \pm 4.2$ & $14.65 \pm 0.62$ & $13.0 \pm 1.3$ & $17.0 \pm 1.9$ & $<2.1$ & $17.2 \pm 1.2$ & $18.4 \pm 3.0$ & $6.8 \pm 1.5$ & $201.9 \pm 8.0$ & $0.210 \pm 0.015$ \\
\hline CEM II/A-L 42.5R & $<3.5$ & $26.7 \pm 3.6$ & $27.1 \pm 2.9$ & $<0.9$ & $27.3 \pm 6.0$ & $<1.18$ & $5.94 \pm 0.35$ & $5.80 \pm 0.75$ & $2.14 \pm 0.32$ & $43.7 \pm 2.9$ & $0.133 \pm 0.012$ \\
\hline CEM II/B-V $42.5 \mathrm{~N}$ & $72 \pm 20$ & $66.8 \pm 7.2$ & $75 \pm 10$ & $68.8 \pm 6.9$ & $56 \pm 19$ & $3.3 \pm 1.2$ & $31.8 \pm 3.1$ & $34.6 \pm 4.8$ & $12.8 \pm 1.5$ & $211.7 \pm 9.1$ & $0.452 \pm 0.029$ \\
\hline CEM III/B $42.5 \mathrm{~N}$ & $99 \pm 20$ & $81 \pm 15$ & $91.9 \pm 4.9$ & $88.5 \pm 2.7$ & $<10.6$ & $3.8 \pm 1.1$ & $50.6 \pm 2.0$ & $52.6 \pm 3.4$ & $20.4 \pm 1.0$ & $184 \pm 11$ & $0.584 \pm 0.051$ \\
\hline CEM I 52,5 S/R & $17.4 \pm 2.9$ & $19.5 \pm 3.2$ & $16.9 \pm 1.9$ & $15.8 \pm 1.0$ & $17.0 \pm 4.4$ & $<2.11$ & $14.3 \pm 1.1$ & $15.7 \pm 1.8$ & $5.50 \pm 0.58$ & $143.5 \pm 9.3$ & $0.184 \pm 0.012$ \\
\hline White cement & $58.5 \pm 3.2$ & - & $57.15 \pm 0.81$ & - & - & - & $4.81 \pm 0.52$ & $4.36 \pm 0.31$ & $1.36 \pm 0.13$ & $84.6 \pm 3.4$ & $0.2428 \pm 0.039$ \\
\hline White cement & $23.7 \pm 3.8$ & $23.5 \pm 3.6$ & $23.1 \pm 2.6$ & $21.9 \pm 1.3$ & $27 \pm 10$ & $<2.13$ & $16.8 \pm 1.2$ & $17.8 \pm 2.1$ & $6.55 \pm 0.70$ & $146.3 \pm 9.1$ & $0.211 \pm 0.014$ \\
\hline CAC & $73.8 \pm 6.2$ & - & $64.9 \pm 0.96$ & - & - & - & $131.2 \pm 1.6$ & $137.4 \pm 1.2$ & $42.42 \pm 0.59$ & $41.4 \pm 5.8$ & $0.886 \pm 0.0088$ \\
\hline CAC & $<19.0$ & $83 \pm 11$ & $82.0 \pm 8.8$ & $<1.2$ & $38.9 \pm 8.3$ & $<12.9$ & $118.4 \pm 5.7$ & $123 \pm 14$ & $45.6 \pm 4.0$ & $<6.8$ & $0.871 \pm 0.046$ \\
\hline Calcium sulfoaluminate & $13.1 \pm 4.0$ & $15.7 \pm 2.9$ & $14.7 \pm 1.7$ & $10.1 \pm 5.6$ & $14.2 \pm 3.8$ & $<2.02$ & $3.85 \pm 0.84$ & $5.01 \pm 0.61$ & $1.73 \pm 0.21$ & $105.0 \pm 7.1$ & $0.107 \pm 0.011$ \\
\hline
\end{tabular}

CAC: calcium aluminate cement

Reproduced with kind permission of Elsevier

TABLE 9. Radionuclides in anhydrous synthetic cements with different SCMs (65).

\begin{tabular}{|c|c|c|c|c|}
\hline \multirow{2}{*}{ Anhydrous cement } & \multicolumn{3}{|c|}{ Radionuclide concentration ( $\mathrm{Bq} \mathrm{kg} \mathbf{~ k g}^{-1}$ ) } & \multirow[b]{2}{*}{ ACI } \\
\hline & ${ }^{226} \mathbf{R a}$ & ${ }^{232} \mathrm{Th}$ & ${ }^{40} \mathbf{K}$ & \\
\hline $\mathrm{OPC}$ & $19.23 \pm 0.54$ & $19.13 \pm 0.32$ & $237.9 \pm 5.2$ & $0.2382 \pm 0.0045$ \\
\hline $\mathrm{OPC}+10 \% \mathrm{SF}$ & $17.49 \pm 0.69$ & $18.41 \pm 0.46$ & $230.6 \pm 5.4$ & $0.2186 \pm 0.0041$ \\
\hline $\mathrm{OPC}+50 \% \mathrm{FA}$ & $72.90 \pm 0.80$ & $74.70 \pm 0.70$ & $277.6 \pm 5.0$ & $0.6951 \pm 0.0060$ \\
\hline $\mathrm{OPC}+50 \% \mathrm{~S}$ & $83.85 \pm 0.90$ & $32.40 \pm 0.50$ & $158.3 \pm 3.7$ & $0.4892 \pm 0.0049$ \\
\hline $\mathrm{OPC}+50 \% \mathrm{~L}$ & $17.91 \pm 0.35$ & $9.65 \pm 0.31$ & $119.8 \pm 2.9$ & $0.1465 \pm 0.0018$ \\
\hline
\end{tabular}

OPC: CEM 52.5R; SF: silica Fume; FA: fly ash; S: ground blast furnace slag; L: limestone

Reproduced with kind permission of Elsevier

TABLE 10. Radionuclide concentration in hydrated cements bearing different types of SCMs (65), determined on ground powdered samples.

\begin{tabular}{|c|c|c|c|c|}
\hline \multirow{2}{*}{ Cement paste } & \multicolumn{3}{|c|}{ Radionuclide concentration ( $\mathrm{Bq} \mathbf{~ k g}^{-1}$ ) } & \multirow[b]{2}{*}{ ACI } \\
\hline & ${ }^{226} \mathbf{R a}$ & ${ }^{232} \mathrm{Th}$ & ${ }^{40} \mathbf{K}$ & \\
\hline OPC & $7.86 \pm 0.60$ & $13.83 \pm 0.60$ & $166.7 \pm 6.7$ & $0.1428 \pm 0.0041$ \\
\hline White Cement & $26.96 \pm 0.73$ & $3.42 \pm 0.16$ & $59.0 \pm 3.2$ & $0.1271 \pm 0.0038$ \\
\hline $\mathrm{CAC}$ & $28.6 \pm 1$ & $98.9 \pm 1.8$ & $17.2 \pm 3.4$ & $0.535 \pm 0.011$ \\
\hline $\mathrm{OPC}+10 \% \mathrm{SF}$ & $6.97 \pm 0.59$ & $13.31 \pm 0.58$ & $165.1 \pm 6.8$ & $0.1384 \pm 0.0057$ \\
\hline $\mathrm{OPC}+50 \% \mathrm{FA}$ & $49.1 \pm 1.3$ & $62.2 \pm 1.1$ & $211.6 \pm 8.0$ & $0.5097 \pm 0.0099$ \\
\hline $\mathrm{OPC}+50 \% \mathrm{~S}$ & $41.5 \pm 1.1$ & $22.76 \pm 0.69$ & $114.1 \pm 5.4$ & $0.2914 \pm 0.0069$ \\
\hline $\mathrm{OPC}+50 \% \mathrm{~L}$ & $9.35 \pm 0.33$ & $7.09 \pm 0.48$ & $7.09 \pm 0.48$ & $0.0928 \pm 0.0044$ \\
\hline
\end{tabular}

OPC: CEM 52.5R; SF: silica Fume; FA: fly ash; S: ground blast furnace slag; L: limestone; CAC: calcium aluminium cement Reproduced with kind permission of Elsevier 
The nature of the fine (sand) and coarse aggregates used in concrete manufacture determines their contribution to the overall radionuclide concentration activity in concrete, although it varies widely. According to Raghu et al. (105), in India the contribution of the sand to ${ }^{226} \mathrm{Ra}$ activity may range from $90 \mathrm{~Bq} \mathrm{~kg}^{-1}$ to $554 \mathrm{~Bq} \mathrm{~kg}^{-1}$; in ${ }^{232} \mathrm{Th}$ from $101 \mathrm{~Bq} \mathrm{~kg}^{-1}$ to $358 \mathrm{~Bq} \mathrm{~kg}^{-1}$ and in ${ }^{40} \mathrm{~K}$ from $280-633 \mathrm{~Bq} \mathrm{~kg}^{-1}$. Figure 7 compares the mean radium equivalent activity of sand to the activity of other Tiruvannamalai building materials (108).

Kovler et al. (63) studied radionuclide concentrations in Israeli building materials and compared the values for different types of standard weight and lightweight aggregates. Their findings are reproduced in Table 12.

As the data in Table 12 show, the lightweight aggregate exhibited higher values in all natural radionuclides, ${ }^{40} \mathrm{~K}$ in particular.

The activity concentrations of the natural uranium, thorium, actinium series and ${ }^{40} \mathrm{~K}$ are known to be high in granite, where the thorium (Th)/uranium (U) mass ratio ranges from 2.25 to 4.67 (17, 109, 110). Granite is a mineral that can be used as a building material in its own right or as fine aggregate in portland cement mortars and concretes. The authors of this review recently studied (under aforementioned project BIA2016-77252-R) the effect of particle size distribution and mineralogical composition of granite from the Spanish region of Galicia on the radiological behaviour of cement mortars (19, 111). According to the findings, granite particle size distribution and mineralogical composition affect radionuclide activity concentration, as may be inferred from Table 13 and Figure 8 (111). The activity concentrations of the thorium and uranium natural decay series were highest in the finest fractions. A correlation was observed between thorium and the $\mathrm{MgO}$ and $\mathrm{Fe}_{2} \mathrm{O}_{3}$ normally present in mica group phyllosilicates. ACI values were higher in granite aggregate than quartz sand mortars (Figure 9) (19).

Very few studies have been conducted on the contribution of concrete admixtures to overall concrete radiological behaviour. The authors of this article, under project BIA2016-77252-R, explored the behaviour of several organic and inorganic admixtures used as pigments or water repellents in concretes and mortars (48). Low radionuclide concentrations were observed except in natural pigments, which raised the ${ }^{238} \mathrm{U}$ series concentration. Those low levels were attributable to the raw material used, namely the red mud generated in aluminium production. The radiological risk for the general public and for workers due to exposure to pigment-modified construction materials was consequently assessed.
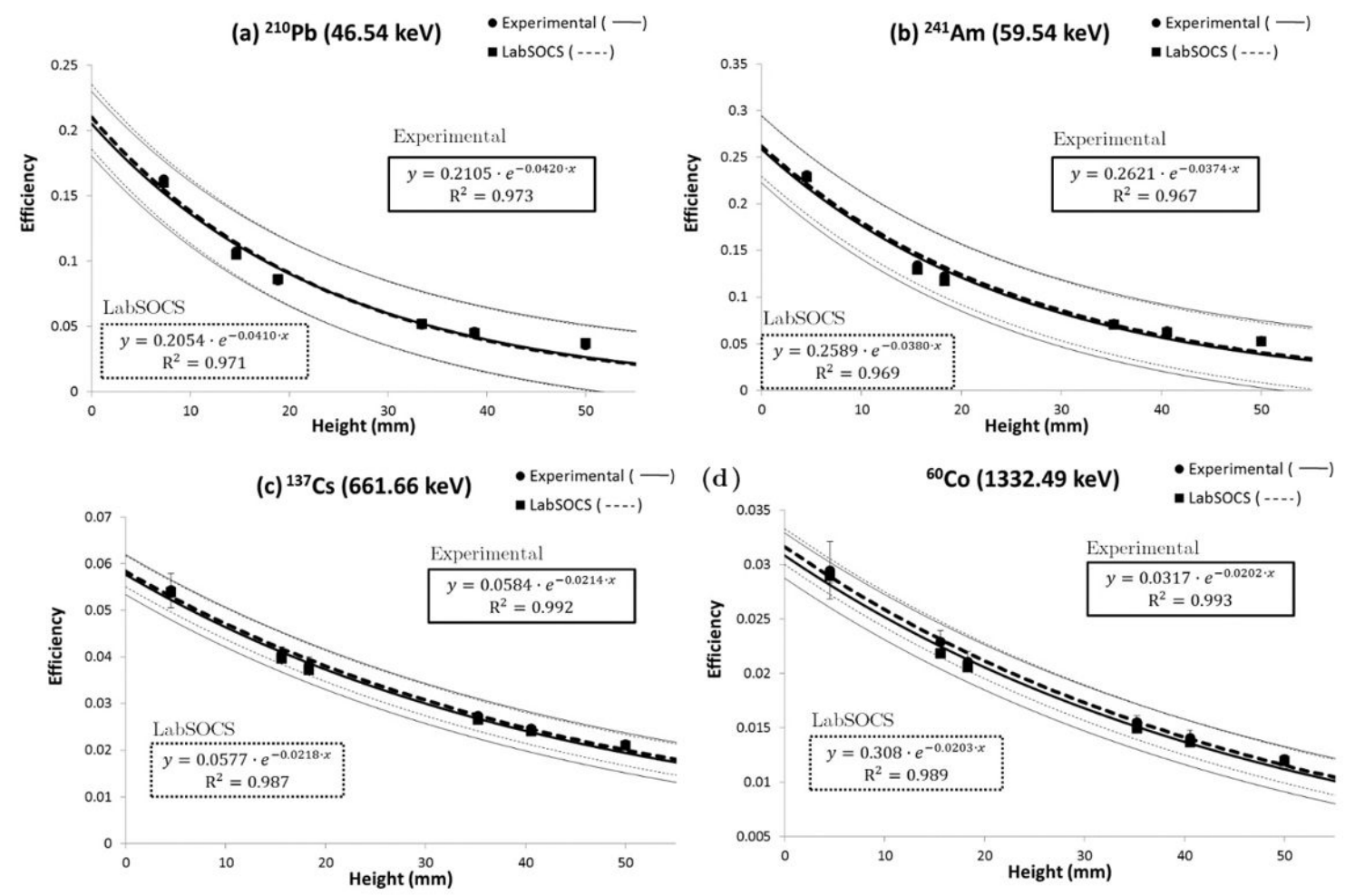

FIGURE 6. Variation in efficiency with the height of quadrangular specimens in the range of energies studied, $46.54 \mathrm{keV}\left({ }^{210} \mathrm{~Pb}\right)$ to $1332.5 \mathrm{keV}\left({ }^{60} \mathrm{Co}\right)(52)$. 
TABLE $11 .{ }^{226} \mathrm{Ra},{ }^{232} \mathrm{Th}$ and ${ }^{40} \mathrm{~K}$ activity concentration in 2727 concrete samples (105).

\begin{tabular}{|c|c|c|c|c|c|c|c|c|c|c|}
\hline \multirow{2}{*}{ Country } & \multirow{2}{*}{$\begin{array}{c}\mathrm{N} \text { of } \\
\text { samples }\end{array}$} & \multicolumn{3}{|c|}{${ }^{222} \mathrm{Ra}\left(\mathrm{Bq} \mathrm{kg}{ }^{-1}\right)$} & \multicolumn{3}{|c|}{${ }^{232} \mathbf{T h}\left(\mathrm{Bq} \mathrm{kg}{ }^{-1}\right)$} & \multicolumn{3}{|c|}{${ }^{40} \mathrm{~K}\left(\mathrm{~Bq} \mathrm{~kg}^{-1}\right)$} \\
\hline & & Average & Min & Max & Average & Min & Max & Average & Min & $\operatorname{Max}$ \\
\hline Austria & 1 & 15 & 7 & 21 & 14 & 3 & 57 & 164 & 16 & 382 \\
\hline Belgium & 37 & 17 & 5 & 42 & 16 & 5 & 42 & 247 & 85 & 490 \\
\hline Bulgaria & 2 & 25 & 19 & 30 & 24 & 17 & 30 & 450 & 200 & 700 \\
\hline Czech Republic & 491 & 33 & & & 24 & & & 495 & & \\
\hline Denmark & 121 & 152 & 15 & 670 & 27 & 10 & 53 & 620 & 280 & 1190 \\
\hline Finland & 294 & 42 & 33 & 53 & 37 & 34 & 39 & 740 & 359 & 964 \\
\hline France & 16 & 44 & 8 & 126 & 40 & 4 & 106 & 88 & 58 & 118 \\
\hline Germany & 75 & 54 & 30 & 100 & 57 & 23 & 100 & 629 & 400 & 1100 \\
\hline Greece & 64 & 40 & 22 & 85 & 6 & 3 & 17 & 101 & 7 & 383 \\
\hline Hungary & 97 & 16 & 13 & 18 & 22 & 11 & 33 & 356 & 204 & 437 \\
\hline Ireland & 8 & 29 & 18 & 68 & 12 & 3 & 13 & 217 & 16 & 1100 \\
\hline Italy & 20 & 19 & 13 & 23 & 18 & 12 & 24 & 329 & 230 & 457 \\
\hline Lithuania & 1 & 32 & & & 17 & & & 426 & & \\
\hline Luxembourg & 2 & 93 & 88 & 98 & 92 & 90 & 93 & 110 & 73 & 146 \\
\hline The Netherlands & 55 & 35 & 10 & 115 & 30 & 6 & 132 & 263 & 140 & 870 \\
\hline Poland & 678 & 115 & 65 & 200 & 72 & 36 & 127 & 666 & 492 & 1005 \\
\hline Portugal & 38 & 61 & 1 & 167 & 50 & 1 & 152 & 747 & 11 & 1450 \\
\hline Romania & 133 & 65 & 17 & 114 & 64 & 16 & 115 & 425 & 163 & 918 \\
\hline Slovakia & 41 & 34 & 11 & 45 & 27 & 7 & 40 & 402 & 251 & 664 \\
\hline Slovenia & 3 & 117 & 20 & 309 & 20 & 10 & 40 & 218 & 105 & 406 \\
\hline Spain & 24 & 30 & & & 32 & & & 204 & & \\
\hline Sweden & 509 & 242 & 42 & 1300 & 70 & 31 & 100 & 627 & 276 & 819 \\
\hline United Kingdom & 17 & 61 & 18 & 89 & 30 & 13 & 42 & 493 & 370 & 650 \\
\hline Overall average & & 60 & & & 35 & & & 392 & & \\
\hline CV (\%) Overall range & & & 1 & 1300 & 1 & 152 & & & 7 & 1450 \\
\hline
\end{tabular}

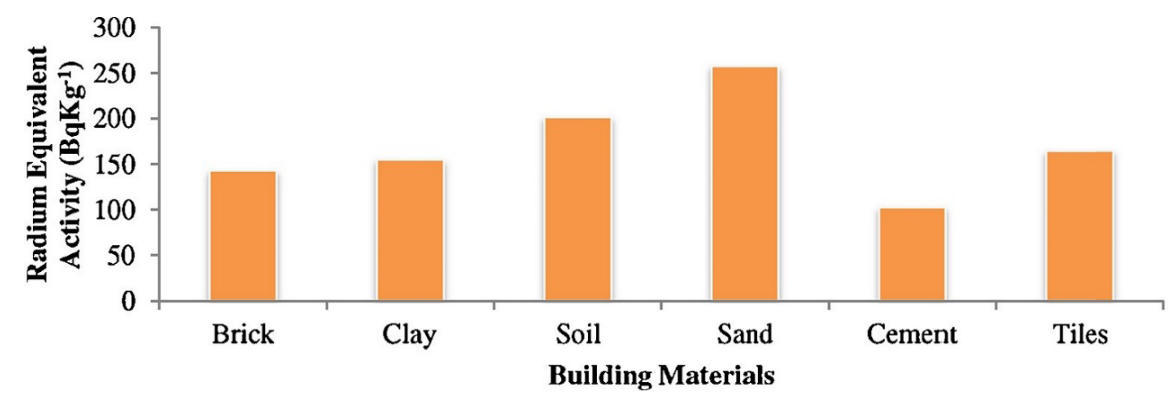

FigURE 7. Mean radium equivalent activity in Tiruvannamalai building materials (108). Reproduced with kind permission of Elsevier. 
TABLE 12. Specific radioactivity $\left(\mathrm{Bq} \mathrm{kg}{ }^{-1}\right)$ of ${ }^{226} \mathrm{Ra},{ }^{232} \mathrm{Th}$ and ${ }^{40} \mathrm{~K}$ in natural aggregates available in Israel (63).

\begin{tabular}{|c|c|c|c|}
\hline \multirow{2}{*}{ Normal weight aggregate } & \multicolumn{3}{|c|}{ Radionuclide concentration $\left(\mathrm{Bq} \cdot \mathrm{kg}^{-1}\right)$} \\
\hline & ${ }^{226} \mathbf{R a}$ & ${ }^{232} \mathbf{T h}$ & ${ }^{40} \mathbf{K}$ \\
\hline Basalt coarse & 12.0 & 13.7 & 308.5 \\
\hline Dolomite coarse & 28.0 & 3.1 & 33.6 \\
\hline Limestone coarse & 18.3 & 7.4 & 77.1 \\
\hline Gravel & 15.0 & 3.0 & 50.4 \\
\hline Limestone sand & 12.1 & 4.1 & 51.1 \\
\hline Quartz sand & 3.1 & 3.7 & 90.9 \\
\hline \multicolumn{4}{|l|}{ Lightweight aggregate } \\
\hline $\begin{array}{l}\text { LECA (Norwegian weight } \\
\text { product, made of expanded clay) }\end{array}$ & 66.1 & 58.3 & 1149.0 \\
\hline $\begin{array}{c}\text { Pumice aggregate (Greek } \\
\text { product) }\end{array}$ & 53.2 & 65.9 & 1155.0 \\
\hline $\begin{array}{l}\text { Experimental aggregate (Israeli } \\
\text { product, made of coal fly ash) }\end{array}$ & 61.2 & 55.1 & 1015.0 \\
\hline Tuff & 33.1 & 41.1 & 534.3 \\
\hline
\end{tabular}

Reproduced with kind permission of Elsevier

TABLE 13. Activity concentration of radioisotopes ${ }^{40} \mathrm{~K},{ }^{214} \mathrm{~Pb}$ and ${ }^{212} \mathrm{~Pb}$ for three types of granite aggregates, standard aggregate and cement (111).

\begin{tabular}{|c|c|c|c|c|c|}
\hline \multirow{2}{*}{\multicolumn{2}{|c|}{ Material (Spanish Region) }} & \multirow{3}{*}{$\begin{array}{l}\text { Size } \\
230 \mu \mathrm{m}\end{array}$} & \multicolumn{3}{|c|}{ Activity concentration ( $\left.\mathrm{Bq} \mathbf{~ k g}^{-1}\right)$} \\
\hline & & & \multirow{2}{*}{$\frac{{ }^{40} \mathbf{K}}{1015 \pm 43}$} & \multirow{2}{*}{$\begin{array}{c}{ }^{214} \mathbf{P b}\left({ }^{(226} \mathbf{R a}\right) \\
200 \pm 30\end{array}$} & \multirow{2}{*}{$\begin{array}{r}{ }^{212} \mathbf{P b}\left({ }^{232} \mathbf{T h}\right) \\
70.5 \pm 5.7\end{array}$} \\
\hline & & & & & \\
\hline & & $0-2 \mathrm{~mm}$ & $1030 \pm 44$ & $207 \pm 31$ & $72 \pm 12$ \\
\hline & Coruña & $0-4 \mathrm{~mm}$ & $1081 \pm 92$ & $180 \pm 27$ & $65 \pm 11$ \\
\hline & & $5-8 \mathrm{~mm}$ & $1206 \pm 104$ & $148 \pm 22$ & $63 \pm 11$ \\
\hline & & $9-20 \mathrm{~mm}$ & $1201 \pm 88$ & $172 \pm 26$ & $95 \pm 16$ \\
\hline & & $230 \mu \mathrm{m}$ & $945 \pm 81$ & $135 \pm 20$ & $99 \pm 16$ \\
\hline & & $0-2 \mathrm{~mm}$ & $875 \pm 75$ & $128 \pm 19$ & $90 \pm 15$ \\
\hline \multirow[t]{8}{*}{ Granite aggregate } & Vigo & $0-4 \mathrm{~mm}$ & $841 \pm 72$ & $115 \pm 17$ & $86 \pm 14$ \\
\hline & & $5-8 \mathrm{~mm}$ & $1244 \pm 106$ & $99 \pm 15$ & $88 \pm 14$ \\
\hline & & $9-20 \mathrm{~mm}$ & $1191 \pm 103$ & $120 \pm 18$ & $120 \pm 20$ \\
\hline & & $230 \mu \mathrm{m}$ & $1032 \pm 88$ & $114 \pm 17$ & $161 \pm 26$ \\
\hline & & $0-2 \mathrm{~mm}$ & $933 \pm 80$ & $96 \pm 15$ & $148 \pm 24$ \\
\hline & Lugo & $0-4 \mathrm{~mm}$ & $1050 \pm 90$ & $90 \pm 14$ & $139 \pm 23$ \\
\hline & & $5-8 \mathrm{~mm}$ & $1347 \pm 115$ & $111 \pm 17$ & $152 \pm 33$ \\
\hline & & $9-20 \mathrm{~mm}$ & $1073 \pm 92$ & $90 \pm 14$ & $79 \pm 13$ \\
\hline \multicolumn{2}{|c|}{ Standard siliceous aggregate } & $0-2 \mathrm{~mm}$ & $147 \pm 13$ & $4.2 \pm 0.71$ & $7.2 \pm 1.2$ \\
\hline \multicolumn{2}{|l|}{ Cement } & & $205 \pm 18$ & $32.0 \pm 4.9$ & $15.0 \pm 2.4$ \\
\hline
\end{tabular}




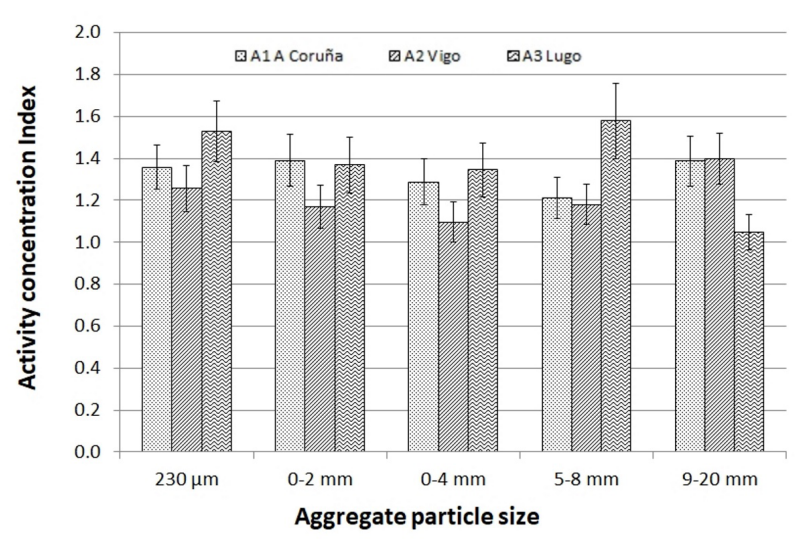

FIGURE 8 . Variation in the activity concentration index with particle size in three types of granite aggregates (111). Reproduced with kind permission of Elsevier.

The doses received by those two communities were neither significant nor constituted any perceptible hazard, essentially in light of the small amounts of pigment used to prepare mortars.

\subsubsection{Alkali-activated cements and concretes. Geopolymers}

Alkali-activated materials (AAMs) are the product of the reaction between a (solid or dissolved) alkaline metal and a solid silicoaluminate powder (binder or precursor). The precursor may be metakaolin, steel or ion mill slag, a natural pozzolan or fly or bottom ash. The alkalinity required is sourced from alkaline hydroxides, silicates, carbonates, sulfates, aluminates or oxides. As many of the precursors and some activators may carry NORM waste, the radionuclide concentration of these alternative cements and mortars should be determined (10).

The radiological behaviour of alkali-activated slag and fly ash cement pastes was first studied by Puertas et al. (65) in vitreous blast furnace slag (BFS) activated with waterglass (AAS) $\left(\mathrm{SiO}_{2} / \mathrm{Na}_{2} \mathrm{O}\right.$ ratio of

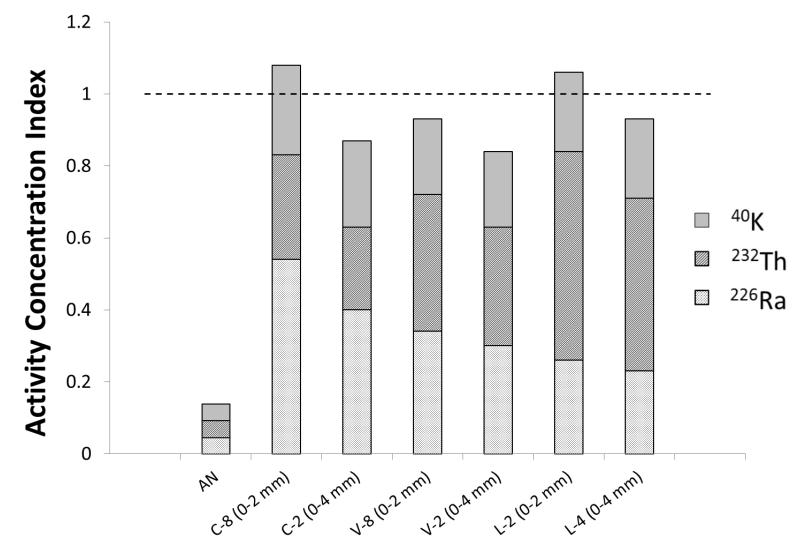

Figure 9. Activity concentration index, ACI, for mortars prepared with standardised (AN) or (Coruña, Vigo or Lugo) granite aggregates with particle sizes $0 \mathrm{~mm}$ to $2 \mathrm{~mm}$ and $0 \mathrm{~mm}$ to $4 \mathrm{~mm}$ (111). Reproduced with kind permission of Elsevier.

0.86 ) and the same precursor activated with $\mathrm{NaOH}$ pre-treated waste glass (waste glass-AAS) at the same $\mathrm{SiO}_{2} / \mathrm{Na}_{2} \mathrm{O}$ ratio. The fly ash(FA) precursor, in turn, was activated with an $8 \mathrm{M} \mathrm{NaOH}$ solution containing $15 \%$ waterglass (N/15Wg-AAFA) as well as with waste glass (waste glass-AAFA). Their findings are summarised in Table 14.

The overall ACI values were higher for fly ash than for vitreous slag and the former were much higher than observed for ordinary Portland cement. Nonetheless, as the values recorded for these geopolymers were consistently lower than 1 , they would be fully compliant with the existing legislation.

A more recent study conducted by Nuccetelli et al. (75) of the radiological behaviour of concretes manufactured with fly ash from five coal-fired power plants in Serbia yielded the results given in Table 15. Their findings also showed ACI values consistently under 1 in all the alkaline concretes analysed.

Other authors report that alkali-activated metakaolin materials are also free of radiological risk (88). That paper also specifies the absorbed dose

TABLE 14. Post-alkaline activation activity concentrations $\left(\mathrm{Bq} \mathrm{kg}^{-1}\right)$ in raw materials (fly ash, BFS and waste glass) and cements (uncertainty, $\mathrm{k}=2)(10,65)$

\begin{tabular}{|c|c|c|c|c|c|c|c|}
\hline Series & & & & ${ }^{232} \mathbf{T h}$ & & ${ }^{40} \mathrm{~K}$ & $\mathbf{A C I} \mathbf{I}^{\mathrm{a}}$ \\
\hline Material & ${ }^{234} \mathrm{Th}$ & ${ }^{214} \mathbf{P b}$ & ${ }^{228} \mathrm{Ac}$ & ${ }^{212} \mathrm{~Pb}$ & ${ }^{208} \mathrm{Tl}$ & & \\
\hline Fly ash & $130 \pm 7.1$ & $127.4 \pm 1.3$ & $130.3 \pm 1.5$ & $133.8 \pm 1.3$ & $41.33 \pm 0.57$ & $316.4 \pm 5.9$ & $1.1815 \pm 0.0089$ \\
\hline BFS & $156.4 \pm 6.8$ & $147.2 \pm 1.4$ & $45.7 \pm 0.86$ & $42.9 \pm 1.2$ & $14.71 \pm 0.30$ & $76.3 \pm 2.7$ & $0.7448 \pm 0.0065$ \\
\hline Waste glass & $11.4 \pm 1.1$ & $8.73 \pm 0.19$ & $5.83 \pm 0.22$ & $6.28 \pm 0.12$ & $1.867 \pm 0.075$ & $226.8 \pm 4.4$ & $0.1338 \pm 0.0020$ \\
\hline Wg-AAS & $91.5 \pm 5.6$ & $48.7 \pm 1.1$ & $22.84 \pm 0.71$ & $23.3 \pm 0.69$ & $7.7 \pm 0.39$ & $77.0 \pm 5.0$ & $0.3022 \pm 0.0054$ \\
\hline Waste glass-AAS & $94.4 \pm 6.7$ & $54.5 \pm 1.4$ & $23.78 \pm 0.81$ & $24.99 \pm 0.83$ & $8.04 \pm 0.41$ & $89.2 \pm 4.8$ & $0.3303 \pm 0.0064$ \\
\hline N/15Wg-AAFA & $56.4 \pm 5.7$ & $36.44 \pm 0.97$ & $67.8 \pm 1.4$ & $75.1 \pm 1.8$ & $21.57 \pm 0.59$ & $578 \pm 15$ & $0.6531 \pm 0.0092$ \\
\hline Waste glass-AAFA & $57.4 \pm 3.2$ & $37.9 \pm 1.1$ & $62.2 \pm 1.2$ & $75.1 \pm 1.2$ & $22.62 \pm 0.63$ & $550 \pm 14$ & $0.6207 \pm 0.0084$ \\
\hline
\end{tabular}


TABLE 15. Natural radionuclide activity concentration in alkali-activated fly ash concretes (75).

\begin{tabular}{lcccc}
\hline \multirow{2}{*}{ AAFASC samples } & ${ }^{232} \mathbf{T h}$ & ${ }^{226} \mathbf{R a}$ & \multirow{2}{*}{ ACI } \\
\cline { 2 - 4 } & & $\left.{ }^{40} \mathbf{K q} \mathbf{~ k g}^{-1}\right)$ & $0.26 \pm 0.1$ \\
C_FA-1 & $18.4 \pm 0.4$ & $28.5 \pm 1.5$ & $232 \pm 4$ & $0.26 \pm 0.1$ \\
C_FA-2 & $18.6 \pm 0.4$ & $28.8 \pm 1.3$ & $225 \pm 4$ & $0.20 \pm 0.1$ \\
C_FA-3 & $12.5 \pm 0.2$ & $21.2 \pm 0.9$ & $196 \pm 3$ & $0.24 \pm 0.1$ \\
C_FA-4 & $14.9 \pm 0.3$ & $27.7 \pm 1.7$ & $218 \pm 3$ & $0.24 \pm 0.1$ \\
C_FA-5 & $16.1 \pm 0.3$ & $28.3 \pm 1.2$ & $197 \pm 3$ & \\
\hline
\end{tabular}

rate (DR) and the annual effective dose rate (EDR), calculated as recommended in the UNSCEAR 2000 report. The authors note that the specific activity of the natural radionuclides in metakaolin resulting from pre-heating kaolin at $750{ }^{\circ} \mathrm{C}$ was 1.6 , while the geopolymer exhibited the lowest specific activities.

The present authors, again under the umbrella of project BIA2016-77252-R, explored the compositions of a number of geopolymer pastes, including hybrid systems (blends of OPC and an activated precursor traditionally used in geopolymers). The precursors included coal fly ash, glassy blast furnace slag and red mud (90). The radiological findings graphed in Figure 10 show that when red mud accounts for $\geq 60 \%$ of a cement or geopolymer, the ACI values exceed 1 . At lower values the waste is Euratom directive-compliant. Croymans et al. (112) contend that to ensure workers receive lower than the safe occupational dose stipulated in Radiation Protection (RP) $122(0.3 \mathrm{mSv} / \mathrm{a})$, building materials should contain less than $75 \mathrm{wt} \%$ of Ukrainian bauxite waste. Applying that same criterion, however, no constraint on the use of Ukrainian bauxite waste would be necessary in road construction.

\section{FINAL REMARKS}

The natural radioactivity of industrial waste/byproducts qualifying for inclusion in building materials, along with the radioactivity of the end products, namely cements and concretes, must be determined to validate their ultimate use and application. That in turn translates into ensuring the doses of those products handled on construction sites are innocuous and working conditions are safe and controlled. The buildings and structures bearing those materials must also comply with all the health and safety criteria and legislation in place that protect building occupants and users.

This review does not address radon (isotope ${ }^{222} \mathrm{Rn}$ ) emanation/exhalation associated with building materials, a matter of particular social, environmental and public health interest. Radon gas is known to have

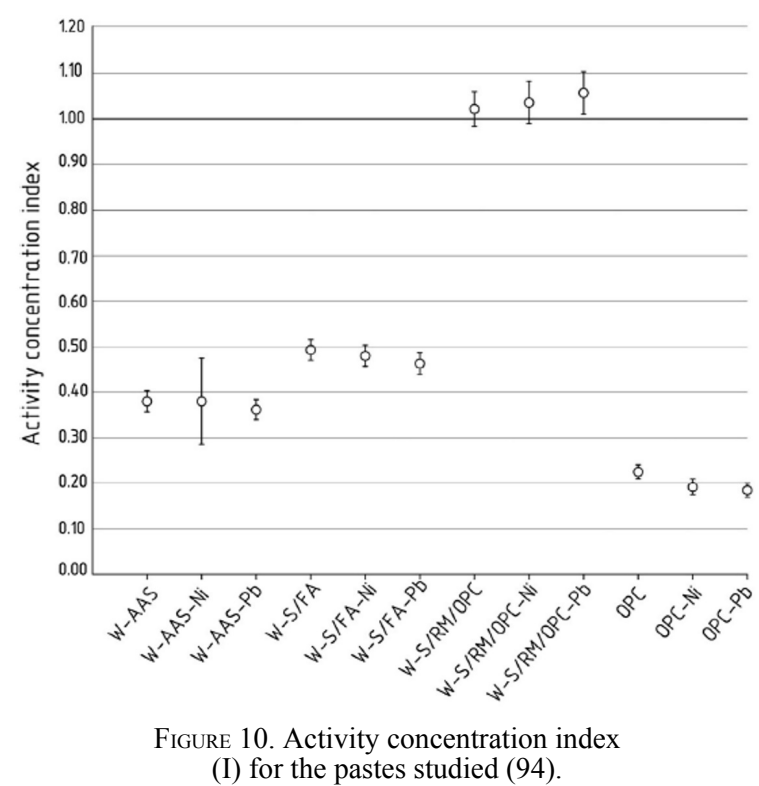

harmful effects on health, particularly as concerns lung cancer (113), with 20000 yearly deaths in the world from that disease attributed or related to radon gas.

More radiological studies and controls should be conducted on all building materials and particularly those bearing or manufactured with waste/by-products. As important as understanding the mechanical strength, soundness and durability of building materials is knowing whether they release radioactivity or other harmful or unhealthy elements during handling and ultimate on-site use.

\section{AUTHOR CONTRIBUTIONS}

Methodology: F. Puertas. Formal analysis: F. Puertas. J.A. Suarez-Navarro. M.M. Alonso, C. Gascó. Investigation: F. Puertas, J.A. Suarez-Navarro, M.M. Alonso, C. Gascó. Data curation: F. Puertas. Writing, original draft preparation: F. Puertas. Writing, review and editing: F. Puertas. J.A. SuarezNavarro. M.M. Alonso, C. Gascó. Supervisión: F. Puertas. Project administration: F. Puertas. Funding acquisition: F. Puertas. 


\section{ACKNOWLEDGEMENTS}

Spanish Ministry of Science and Innovation funding for project BIA2016-77252-R, under which several of the studies described in this review were conducted, is gratefully acknowledged.

\section{REFERENCES}

1. Mindess, S. (2019) Sustainability of Concrete. Chapter 1. Sustainability of Concrete. Modern Concrete Techonology Book 17. Ed.: Routledge.

2. Circular Economy. UE: https://ec.europa.eu/commission/ priorities/jobs-growth-and-investment/towards-circulareconomy es, 2016

3. ONU. Sūstainability Development Goals. Paris. 2015. https://www.agenda2030.gob.es/

4. Roadmap 2020. European Commission. https://www.roadmap2050.eu.

5. García-Díaz. I.; Puertas, F. (2011) Empleo de residuos cerámicos como materia prima alternativa en la fabricación de cemento Portland (in spanish). Monografías del IETcc. Ed. CSIC.

6. Savić, A.; Martinović, S.; Vlahović, M.; Volkov-Husović, T. (2020) Effects of waste sulfur content on properties of self-compacting concrete. Mater. Construcc. 70 [338], e216, https://doi.org/10.3989/mc.2020.06919.

7. Gonzalez-Triviño, I; Pascual-Cosp, J.; Moreno, B; Benitez-Guerrero, M. (2019) Manufacture of ceramics with high mechanical properties from red mud and granite waste. Mater. Construcc. 69 [333], e180, https://doi.org/ 10.3989/mc.2019.03818.

8. Scrivener, K.L.; John, V. M.; Gartner, E.M. (2016) Ecoefficient cements: Potential, economically viable solutions for a low- $\mathrm{CO}_{2}$, cement based materials industry. United Nations \& Environment Programm, 2016.

9. Mora, J.C.; Baeza, A.; Robles, B.; Sanz, J. (2016) Assessment for the management of NORM wastes in conventional hazardous and nonhazardous waste landfills. J. Haz. Mat. 310, 161-169, https://doi.org/10.1016/j.jhazmat.2016.02.039.

10. Labrincha, J.; Puertas, F.; Schroeyers, W.; Kovler, K.; Pontikes, Y.; Nuccetelli, C.; Krivenko, P.V.; Kovalchuk, O. Petropavlovsky, O.; Komljenovic, M.; Fidanchevski, E.; Wiegers, R.; Volceanov. E.; Gunay, E.; Sanjuán, M. A.; Ducman, V.; Angjusheva, B.; Bajare, D.; Kovacs, T.; Bator, G.; Schreurs, S.; Aguiar, J.; Provis, J.L. (2017) From NORM by-products to building materials. In Naturally Ocurring Radiactive Materials in Construction. Chapter 7. Ed. W. Schroeyers. Elservier, 183-252, https://doi.org/ 10.1016/B978-0-08-102009-8.00007-4

11. Martín Matarranz, J.L. (2013) Riesgo Radiológico de las industrias no nucleares. Ph. D Thesis. Universidad de Cantabria.

12. Kovler K. Fridman, $\mathrm{H}$; Michalik, B; Schroeyers, W Tsapalov, A.; Antropov, S.; Bituh, T.; Nicolaides, D. (2017) Basic aspects of natural radioactivity. In Naturally Ocurring Radiactive Materials in Construction. Ed. W. Schroeyers. Elservier. Chapter 3. 13-16.

13. Piedecausa García, B.; Chinchón Payá, S.; Morales, M.A.; Sanjuán Barbudo, M.A. (2011) Radiactividad natural de los materiales de construcción. Aplicación al hormigón. Parte II. Radiación interna: Gas radón. Cemento y Hormigón. 946, 34-50

14. Pastor, A.; Dovorzhak, A.; Mora, J.C. (2016) Hacia un inventario español de industrias generadoras de residuos NORM. Radioprotección. 86, 28-32.

15. Orden IET/1946/2013, de 17 de octubre, por la que se regula la gestión de los residuos generados en las actividades que utilizan materiales que contienen radionucleidos naturales. 23 de octubre de 2013 (in spanish).
16. Allam, M.E.; Bakhoum, E.S.; Gara, G.L.K. (2014) Re-use of granites sludge in producing Green concrete. ARPN. J. Eng. Appl. Sci. 9 [12], e2737. 2731-2737.

17. Condomines, M.; Hemond, C.; Allègre, C. (1988) UThRa radioactive disequilibria and magmatic processes. Earth Planet. Sci. Lett. 90 [3], 243-262.

18. Plant, J.A.; Saunders, A. D. (1996) The Radioactive Earth Rad. Protec. Dosim. 68 [1-2], 25-36.

19. Suárez-Navarro, J.A.; Alonso, M.M.; Gascó, C.; Pachón, A.; Carmona-Quiroga, P.M.; Argiz, C.; Sanjuán, M.A.; Puertas, F. (accepted 2021) Effect of particle size and composition of granitic sands on the radiological behavior of mortars. Bol. Soc. Esp. Cer. Vid. Available online 2 June 2021. https://doi.org/10.1016/j.bsecv.2021.05.001.

20. Kovacs, T.; Bator, G.; Schroeyers, W.; Labrincha, J.; Puertas, F.; Hegedus, M.; Nicolaides, D.; Sanjuán, M.A.; Krivenko, P.V.; Grubesa, I.N.; Sas, Z.; Michalic, B.; Anagnostakis, M.; Barisic, I.; Nuccetelli, C.; Trevisi, R.; Croymans, T.; Schreurs, S.; Todorovic, N.; VaičiukynienePalubinskaite, D.; Bistrickaitè, R.; Tkaczyk, A.; Kovler, K.; Wiegers, R.; P.V.; Doherty, R. (2017) From raw materials to NORM by-products. In Naturally Ocurring Radiactive Materials in Construction. Chapter 6. Ed. W. Schroeyers. Elservier. 135-182. https://doi.org/10.1016/B978-0-08-10 2009-8.00006-2.

21. EN-197-1: (2011). Part 1: Composition, specifications and conformity criteria for common cements.

22. Puertas, F.; Blanco-Varela, M. T.; Palomo, A.; Vázquez, T. (1988) Reactivity and burnability of raw mixes made with crystallized blastfurnace slags. Part I. and Part II. ZementKalk-Gips; 41, (389-402) and (628-631).

23. Puertas, F.; García-Díaz, I.; Palacios, M.; Gazulla, M.F.; Gómez, M.P.; Orduña, M. (2010) Clinkers and cements obtained from raw mix containing ceramic waste as a raw material. Characterization, hydration and leaching studies. Cem. Concr. Comp. 32 [3], 175-186 https://doi.org/10. 1016/j.cemconcomp.2009.11.011.

24. Blanco-Varela, M. T.; Puertas, F.; Palomo, A.; Vázquez, T.; Artola, P.; Alfaro, L. (2000) Aptitud a la cocción de crudos de cemento Portland usando Paval como materia prima. Cemento y Hormigón (in Spanish) 809, 358-377.

25. Puertas, F.; Blanco-Varela, M.T. (2004). Use of alternative fuels in cement manufacture. Effect on clinker and cement characteristics and properties. Mater. Construcc. 54 [274], 51-64. https://doi.org/10.3989/mc.2004.v54.i274.232.

26. Palomo, A.; Krivenko, P.; Garcia-Lodeiro, I.; Kavalerova, E.; Maltseva, O.; Fernández-Jiménez, A. (2014) A review on alkaline activation: new analytical perspectives. Mater. Construcc. 64 [315], e022. https://doi.org/10.3989/mc.20 14.00314.

27. Robayo-Salazar, R.; Mejía de Gutierrez, R.; Puertas, F (2019) Alkali-activated binary concrete based on a natural pozzolan: physical, mechanical and microstructural characterization. Mater. Construcc. 69 [335], e191 https:// doi.org/10.3989/mc.2019.06618.

28. Pacheco-Torgal, F.; Labrincha, J.A.; Leonelli, C.; Palomo, A.; Chindaprasirt, P. (Eds.). (2015) Handbook of Alkaliactivated cements, mortars and concretes. Woodhead Publishing Series in Civil and Structural Engineering.

29. Provis, J.L.; van Deventer, J.J. (Eds). (2014) Alkali Activated Materials. State of the Art Report, ILEM TC 224-AAM. Springer. https://doi.org/10.1007/978-94007-7672-2.

30. Shi, C.; Krivenko, P.; Roy, D. (2006) Alkali-Activated Cements and Concretes. Taylor and Francis, London and New York.

31. Shi, C.; Fernández Jiménez, A.; Palomo, A. (2011) New cements for the 21 st century: The pursuit of an alternative to Portland cement. Cem. Concr. Res., 41, 750-763, https:// doi.org/10.1016/j.cemconres.2011.03.016.

32. Puertas, F.; Torres-Carrasco, M. (2014) Use of glass waste as an activator in the preparation of alkali-activated slag cements. Mechanical strength and paste characterisation. Cem. Concr. Res., 57, 95-104. https://doi.org/10.1016/ j.cemconres.2013.12.005. 
33. Torres-Carrasco, M.; Puertas, F. (2015). Waste glass in the geopolymer preparation. Mechanical and microstructura characterisation. J. Clean. Prod. 90, 397-408. https:// doi.org/10.1016/j.jclepro.2014.11.074.

34. Mejía, J.M.; Mejía de Gutiérrez, R.; Puertas, F. (2013) Rice husk ash as a source of silica in alkali-activated fly ash and granulated blast furnace slag systems. Mater. Construcc. 63 [311], 361-375. https://doi.org/10.3989/mc.2013.04712.

35. Shi, C.; Shi, Z.; Hu, X.; Zhao, R.; Chong, L. (2015) A review on alkali-aggregate reactions in alkali-activated mortars/concretes made with alkali-reactive aggregates. Mater. Struct. 48, 621-628. https://doi.org/10.1617/s11 527-014-0505-2.

36. Pérez-Cortes, P.; Escalante-García, J.I. (2020) Alkali activated metakaolin with high limestone contentsStatistical modeling of strength and environmental and cost analyses. Cem. Concr. Comp. 106, 103450 https://doi.org/ 10.1016/j.cemconcomp.2019.103450.

37. Puertas, F.; Martínez-Ramírez, S.; Alonso, S.; Vázquez, T. (2000) Alkali-activated fly ash/slag cement. Strength behaviour and hydration products. Cem. Concr. Res. 30 [10], 1625-1632. https://doi.org/10.1016/S0008-8846(00) 00298-2.

38. Torres-Carrasco, M.; Puertas, F. (2017) Waste glass as a precursor in alkaline activation: chemical process and hydration products. Construc. Build. Mat. 139, 342-354 https://doi.org/10.1016/j.conbuildmat.2017.02.071.

39. Payá, J.; Agrela, F.; Rosales, J.; Martín Morales, M. Borrachero, M.V. (2019) Application of alkali-activated industrial waste. New Trends Eco-effic. Recyc. Concr. 357-424. https://doi.org/10.1016/B978-0-08-102480-5. 00013-0.

40. Mas, M.A.; Tashima, M.M.; Payá, J.; Borrachero, M.V.; Soriano, L; Monzó, J.A. (2015) A binder from alkali activation of FCC waste: Use in roof tiles fabrication. Key Eng. Mat. 668, 411-418. https://doi.org/10.4028/ww w.scientific.net/KEM.668.411.

41. Puertas, F.; Barba, A.; Gazulla, M.F.; Gómez, M.P.; Palacios, M.; Martínez-Ramírez, S. (2006) Ceramic wastes as raw materials in pórtland cement clinker fabrication: characterization and alkaline activation. Mater. Construcc. 56 [281], 73-84 https://doi.org/10.3989/mc.2006.v56. i281.94.

42. Burciaga-Díaz, O; Durón-Sifuentes, M.; Díaz-Guillén J.A.; Escalante-García, J.I. (2020) Effect of waste glass incorporation on the properties of geopolymers formulated with low purity metakaolin. Cem. Concr. Comp. 107, 103492 https://doi.org/10.1016/j.cemconcomp.2019.103 492.

43. Alonso, M.M.; Gascó, C.; Martín Morales, M.; SuárezNavarro, J.A.; Zamorano, M.; Puertas, F. (2019) Olive Biomas ash as an alternative activator in geopolymer formation: A study of strenth, radiology and leaching behaviour. Cem. Concr. Comp. 104, 103384. https://doi.org/ 10.1016/j.cemconcomp.2019.103384.

44. de Moraes Pinheiro, S.M.; Font, A.; Soriano, L.; Tashima, M.M.; Monzó, J.M.; Borrachero, M.V.; Payá, J. (2018) Olive-stone biomass ash (OBA): An alternative alkaline source for the blast furnace slag activation. Construc. Build. Mat. 178, 30. 327-338. https://doi.org/10.1016/ j.conbuildmat.2018.05.157.

45. Deloitte (2017) Study on Resource Efficient Use of Mixed Wastes, Improving of construction and demolition waste Final Report. Prepared for the 631 European Commission, DG ENV [31] DWC.

46. Pellegrino, C.; Faleschini, F.; Meyer, C. (2019) Recycled Materiales in Concrete, Chapter 2. Sustainability of Concrete. Ed. Pierre-Claude AÍtcin, Sidney Mindess, Modern Concrete Technology 17.

47. Zhang, L.W.; Sojobi, A.O.; Kodur, V.K.R.; Liew, K.M. (2019) Effective utilization and recycling of mixed recycled aggregates for a greener environment. J. Clean. Prod. 236, 117600. https://doi.org/10.1016/j.jclepro.20 19.07.075.

48. Suarez-Navarro, J.A.; Lanzón, M.; Moreno-Reyes, A.M.; Gascó, C.; Alonso, M.M.; Blanco-Varela, M.T.; Puertas, F. (2019). Radiological behaviour of pigments and water repellents in cement-based mortars. Construc. Build. Mat. $225, \quad 879-885$. https://doi.org/10.1016/j.conbuildmat.20 19.07.271

49. I.A.E.A. Extent of Environmental Contamination by Naturally Occurring Radioactive Material (NORM) and Technological Options for Mitigation. Tech. Reports Ser. 419. Vienna, Austria 419. (2003).

50. CEN/TC 351. Construction products: Assessment of release of dangerous substances. Radiation from construction products - Dose assessment and classifications of emitted gamma radiation. (2013)

51. Council Directive 2013/59/Euratom of 5 December 2013 laying down basic safety standards for protection against the dangers arising from exposure to ionising radiation, and repealing Directives 89/618/Euratom, 90/641/Euratom, 96/29/Euratom, 97/43/Euratom and 2003/122/Euratom.

52. Suárez-Navarro, J.A.; Moreno-Reyes, A.M.; Gascó, C. Alonso, M.M.; Puertas, F. (2020) Gamma spectrometry and LabSOCS-calculated efficiency in the radiological characterisation of quadrangular and cubic specimens of hardened portland cement paste. Rad. Phys. Chem. 171, 108709. https://doi.org/10.1016/j.radphyschem.2020.10 8709.

53. Suárez-Navarro, J. A.; Gascó, C.; Alonso, M.M.; BlancoVarela, M.T.; Lanzón, M.; Puertas, F. (2018) Use of Genie 2000 and Excel VBA to correct for $\gamma$-ray interference in the determination of NORM building material activity concentrations. Appl. Radi. Isot. 142, 1-7. https://doi.org/ 10.1016/j.apradiso.2018.09.019.

54. Argiz, C.; Menéndez, E.; Moragues, A.; Sanjuán, M.A (2015) Fly ash characteristics of Spanish coal-fired power plants. Afinidad. 72 [572], 269-277. http://www.raco.cat/ index.php/afinidad/article/view/305569/395407.

55. Skibsted, J.; Snellings, R. (2019) Reactivity of supplementary cementitious Materials (SCMs) in cement blends. Cem. Concr. Res. 124, 105799 https://doi.org/ 10.1016/j.cemconres.2019.105799.

56. Mora, J.C.; Robles, B.; Corbacho, J.A.; Gascó, C.; Gázquez, M.J. (2011). Modelling the behaviour of ${ }^{210} \mathrm{Po}$ in high temperatura processes. J. Environ. Radioac. 102 [5], 520-526. https://doi.org/10.1016/j.jenvrad.2010.10.006.

57. Temuujin, J.; Surenjav, E.; Ruescher, C.H.; Vahlbruch, J. (2019) Processing and uses of fly ash addressing radioactivity (critical review), Chemosph. 216, 866-88. https://doi.org/10.1016/j.chemosphere.2018.10.112.

58. Zielinski, R.A.; Finkelman, R.B. (1997) Radioactive elements in coal and fly ash: abundance, forms, and environmental significance, US Geological Survey, 2327-6932.

59. World Nuclear Association. Naturally Occuring Radioactive Materials (july, 2015). https://www.world-nuclear.org/information-library/safety-and-security/radiationand-health/naturally-occurring-radioactive-materialsnorm.aspx.

60. Karangelos, D.J.; Petropoulos, N.P.; Anagnostakis, M.J.; Hinis, E.P.; Simopoulos, S.E. (2004) Radiological characteristics and investigation of the radioactive equilibrium in the ashes produced in lignite-fired power plant. J. Env. Rad. 77 [3], 233-246. https://doi.org/10.1016/ j.jenvrad.2004.03.009.

61. Mora, J.C.; Baeza, A.; Robles, B.; Corbacho, J.A.; Cancio, D. (2009). Behaviour of natural radionuclides in coal combustión. Radioprotec. 44 [5], 577-580.

62. Nuccetelli, C.; Pontikes, Y.; Leonardi, F.; Trevisi, R. (2015) New perspectives and issues arising from the introduction of (NORM) residues in building materials: A critical assessment on the radiological behaviour. Construc. Build. Mat. 82, 323-331. https://doi.org/10.1016/j.conbuildmat.2015.01.069

63. Kovler, K.; Haquin, G.; Manasherov, V.; Ne'eman, E. Lavi, N. (2002) Natural radionuclides in building materials available in Israel. Build. Environ. 37 [5], 531-537. https:// doi.org/10.1016/S0360-1323(01)00048-8.

64. Piedecausa, B.; Chinchón-Payá, S.; Morales, M.A.; Sanjuán, M.A. (2011) Radioactividad natural de los materiales de construcción. Aplicación al hormigón. Parte 1. Radiación externa: índice de riesgo radiactivo. Cem. Horm. 945, 40-65. 
65. Puertas, F.; Alonso, M.M.; Torres-Carrasco, M.; Rivilla, P.; Gasco, C.; Yagüe, L.; Suárez, J. A.; Navarro, N. (2015 Radiological characterization of anhydrous/hydrated cements and geopolymers. Construc. Build. Mat. 101 [1], 1105-1112. https://doi.org/10.1016/j.conbuildmat.2015. 10.074 .

66. Alonso, M.M.; Suárez-Navarro, J.A.; Pérez-Sanz, R.; Gascó, C.; Moreno de los Reyes, A.M.; Lanzón, M. Blanco-Varela, M.T.; Puertas, F. (2020) Data in Brief. 33, 106488. https://doi.org/10.1016/j.dib.2020.106488.

67. Kovler, K.; Perevalov, A.; Steiner, V.; Metzger, L.A. (2005) Radon exhalation of cementitious materials made with coa fly ash: Part 1 - scientific background and testing of the cement and fly ash emanation. J. Env. Rad. 82 [3], 321-324. https://doi.org/10.1016/j.jenvrad.2005.02.004

68. Chinchón-Payá, S.; Piedecausa, B.; Hurtado, S.; Sanjuán, M.A.; Chinchón, S. (2011) Radiological impact of cement, concrete and admixtures in Spain. Rad. Meas. 46 [8], 734-735. https://doi.org/10.1016/j.radmeas.2011.06.020.

69. Gupta, M.; Kumar Mahur, A.; Varshney, R.; Sonkawade, R.G.; Verma, K.D.; Prasad, R. (2013) Measurement of natural radioactivity and radon exhalation rate in fly ash samples from a thermal power plant and estimation of radiation doses. Rad. Meas. 50, 160-165. https://doi.org/ 10.1016/j.radmeas.2012.03.015

70. Kovler, K. (2012) Does the utilization of coal fly ash in concrete construction present a radiation hazard? Construc. Build. Mat. 29, 158-166. https://doi.org/10.1016/j.conbuildmat.2011.10.023

71. Ignjatović, I.; Sas, Z.; Dragaš, J.; Somlai, J.; Kovács, T. (2017) Radiological and material characterization of high volume fly ash concrete. J. Env. Rad. 168, 38-45. http:// doi.org/10.1016/j.jenvrad.2016.06.021.

72. Temuujin, J.; Minjigmaa, A.; Davaabal, B; Bayarzul, U. Ankhtuya, A.; Jadambaa, Ts.; MacKenzie, K.J.D. (2014 Utilization of radioactive high-calcium Mongolian flyash for the preparation of alkali-activated geopolymers for safe use as construction materials. Ceram. Int. 40, [10], 16475-16483. https://doi.org/10.1016/j.ceramint.2014.0 7.157 .

73. Man-yin, W. T.; Leung, J.K.C. (1996) Radiological Impact of Coal Ash from the Power Plants in Hong Kong. J. Env. Rad. 30 [1], 1-14. https://doi.org/10.1016/0265-931X(95) 00042-9.

74. Turhan, Ş. (2008) Assessment of the natural radioactivity and radiological hazards in Turkish cement and its raw materials. J. Env. Rad. 99 [2], 404-414. https://doi.org/ 10.1016/j.jenvrad.2007.11.001.

75. Nuccetelli, C.; Trevisi, R.; Ignjatović, I.; Dragaš, J. (2017) Alkali-activated concrete with Serbian fly ash and its radiological impact. J. Env. Rad. 168, 30-37. https:// doi.org/10.1016/j.jenvrad.2016.09.002.

76. Puertas, F. (1993) Escorias de alto horno: composición y comportamiento hidraúlico. Mater. Construcc. 43 [229], 37-48. https://doi.org/10.3989/mc.1993.v43.i229.687.

77. Pellegrino, C.; Faleschini, F.; Meyer, C. (2019). Recycled Materials in Concrete. Chapter 2. Sustainability of Concrete. Modern Concrete Techonology Book 17. Routledge Ed.

78. Liapis, I.; Papayianni, I. (2015) Advances in chemical and physical properties of electric arc furnace carbon steel slag by hot stage processing and mineral mixing. J. Haz. Mat. 283, 89-97 https://doi.org/10.1016/j.jhazmat.2014.08.072.

79. Rodríguez, A.; Santamaría-Vicario, I.; Calderón, V.; Junco, C.; García-Cuadrado, J. (2019) Study of the expansión of cement mortars manufactured with landle furnace slag LFS. Mater. Construcc. 69 [334], e183. https://doi.org/ 10.3989/mc.2019.06018

80. Liu, J.; Yu, B.; Wang, Q. (2020) Application of steel slag in cement treated aggregate base course. J. Clean. Prod. 269 121733. https://doi.org/10.1016/j.jclepro.2020.121733.

81. Cooper, M.B. (2005) Naturally Ocurring Radioactive Materials (NORM) in Australian Industries- Review of Current Inventories and Future Generation. EnviroRad Serv. Pty. Ltd. ARPANSA. Melbourne.

82. Gijbels, K.; Iacobescu, R.I.; Pontikes, Y.; Vandevenne, N Schreurs, S.; Schroeyers, W. (2018) Radon immobilization potential of alkali-activated materials containing ground granulated blast furnace slag and phosphogypsum. Construc. Build. Mat. 184, 68-75. https://doi.org/10.1016/ j.conbuildmat.2018.06.162.

83. Argiz, C.; Reyes, E.; Moragues, A. (2018) Ultrafine portland cement performance. Mater. Construcc. 68 [330], e157. https://doi.org/10.3989/mc.2018.03317.

84. Goldman, A.; Bentur, A. (1993) The influence of microfillers on enhancement of concrete strength. Cem. Concr. Res. 23 [4], 962-972. https://doi.org/ 10.1016/0008-8846(93)90050-J

85. Instrucción de hormigón estructural (EHE-08) (2008). BOE 203. https://www.fomento.es/nr/rdonlyres/e20dffb7-fd7 5-4803-8ca4-025064bb1c40/68186/1820103 2008.pdf" (In spanish).

86. Soria Santamaría, F. (1983) Las puzolanas y el ahorro energético en los materiales de construcción. Mater. Construcc. 33 [190-191], 69-84. https://doi.org/10.3989/ mc.1983.v33.i190-191.974

87. Robayo-Salazar, R.; Mejía de Gutiérrez, R.; Puertas, F. (2019) Alkali-activated binary concrete based on a natural pozzolan: physical, mechanical and microstructural characterization. Mater. Construcc. 69 [335], e191. https:// doi.org/10.3989/mc.2019.06618.

88. Ivanović, M.; Kljajević, Lj.; Nenadović, M.; Bundaleski, N.; Vukanac, I.; Todorović, B.; Nenadović, S. (2018) Physicochemical and radiological characterization of kaolin and its polymerization products. Mater. Construcc. 68 [330], e155 https://doi.org/10.3989/mc.2018.00517.

89. Voglis, N.; Kakali, G.; Chaniotakis, E.; Tsivilis, S. (2005) Portland-limestone cements. Their properties and hydration compared to those of other composite cements. Cem. Concr. Comp. 27 [2], 191-196. https://doi.org/10.1016/ j.cemconcomp.2004.02.006.

90. Skaropoulou, A.; Tsivilis, S.; Kakali, G.; Sharp, J. H.; Swamy, R. N. (2009) Long term behavior of Portland limestone cement mortars exposed to magnesium sulfate attack. Cem. Concr. Comp. 31 [9], 628-636 https://doi.org/ 10.1016/j.cemconcomp.2009.06.003

91. Turhan, Ş.; Baykan, U.N.; Şen, K. (2008) Measurement of the natural radioactivity in building materials used in Ankara and assessment of external doses. J. Rad. Protec. 28 [1], 83-91. https://doi.org/10.1088/0952-4746/28/1/005.

92. Turhan, S.; Gürbüz, G. (2008) Radiological significance of cement used in building construction in Turkey. Rad. Protec. Dos. 129 [4], 391-396. https://doi.org/10.1093/rpd/ ncm454.

93. Xhixha, G.; Bezzon, G.P.; Broggini, C.; Buso, G.P. Caciolli, A.; Callegari, I.; De Bianchi, S.; Fiorentini, G.; Guastaldi, E.; Kaçeli Xhixha, M.; Mantovani, F.; Massa, G.; Menegazzo, R.; Mou, L.; Pasquini, A.; Rossi Alvarez, C.; Shyti, M. (2013) The worldwide NORM production and a fully automated gamma-ray spectrometer for their characterization. J. Radioanal. Nucl. Chem. 295, 445-457. https://doi.org/10.1007/s10967-012-1791-1.

94. Alonso, M.M.; Pasko, A.; Gascó, C.; Suarez, J.A.; Kovalchuk, O.; Krivenko, P.; Puertas, F. (2018) Radioactivity and $\mathrm{Pb}$ and $\mathrm{Ni}$ immobilization in SCMbearing alkali-activated matrices. Construc. Build. Mat. 159, 745-754. https://doi.org/10.1016/j.conbuildmat.201 7.11.119.

95. Maldonado-García, M. A.; Hernández-Toledo, U. I.; Montes-García, P.; Valdez-Tamez, P. L. (2018) The influence of untreated sugarcane bagasse ash on the microstructural and mechanical properties of mortars. Mater. Construcc. 68 [329], e148. https://doi.org/10.3989/ mc.2018.13716

96. Pereira, A.M.; Moraes, J.C.B.; Moraes, M.J.B.; Akasaki, J.L.; Tashima, M.M.; Soriano, L.; Monzó, J.; Payá, J. (2018). Valorisation of sugarcane bagasse ash (SCBA) with high quartz content as pozzolanic material in Portland cement mixtures. Mater. Construcc. 68 [330], e153. https:// doi.org/10.3989/mc.2018.00617.

97. Gupta, A.; Gupta, N.; Shukla, A.; Goyal, R.; Kumar, S. (2020) Utilization of recycled aggregate, plastic, glass waste and coconut shells in concrete - a review. IOP Conf. Series: Mat. Sci. Eng. 804, 012034. https://doi.org/ $10.1088 / 1757-899 X / 804 / 1 / 012034$ 
98. Kou, S.C.; Poon, C.S. (2009) Properties of self-compacting concrete prepared with recycled glass aggregate. Cem. Concr. Comp. 31 [2], 107-113. https://doi.org/10.1016/ j.cemconcomp.2008.12.002.

90 (1986) Natural radioactivity in Mexican building Materials by SSNT. Nuclear Tracks Rad. Meassu. 12, [1-6], 767-770.

100. García-Díaz, I.; Gázquez, M.J.; Bolivar, J.P.; López, F.A. (2016) Characterization and valoration of Norm wastes for construction materials - Chapter 2. Manag. Haz. Wast. 13-37 (2016). Ed. INTECH. https://doi.org/10.5772/63196.

101. Dvorkin, L.; Lushnikova, N.; Sonebi. M. (2018) Application areas of phosphogypsum in production of mineral binders and composites based on them: a review of research results. MATEC Web of Confe. 149, 01012. https:// doi.org/10.1051/matecconf/201814901012.

102. Ngoc Lam, N. (2020) Eco-concrete made with phosphogypsum-based super sulfated cement. IOP Conf. Series: Mater. Scie. and Engi. 869, 032031. IOP Publishing. https://doi.org/10.1088/1757-899X/869/3/03 2031.

103. IAEA. (2013) Radiation protection and management of NORM residues in the phosphate industry. Safety Reports Series 78. http://refhub.elsevier.com/B978-0-08-1020098.00006-2/rf0225.

104. Kovler, K.; Dashevsky, B.; Kosson, D.S.; Reches, Y. (2017) US Patent. System and methods for removing impurities from phosphogypsum and manufacturing gypsum binder. US 2017/0022070A1.

105. Trevisi, R.; Risica, S.; D’Alessandro, M.; Paradiso, D.; Nuccetelli. C. (2012) Natural radioactivity in building materials in the European Union: a database and an estimate of radiological significance. J. Env. Rad. 105, 11-20. https://doi.org/10.1016/j.jenvrad.2011.10.001.

106. Sanjuán, M.A.; Suarez-Navarro, J.A.; Argiz, C.; Mora, P. (2019). Assessment of radiation hazards of white and grey
Portland cements. J. Radioanal. Nucl. Chem. 322, 1169-1177. https://doi.org/10.1007/s10967-019-06824-y.

107. Sanjuán, M.A.; Suárez-Navarro, J.A.; Argiz, C.; Mora, P. (2020) Assessment of natural radioactivity and radiation hazards owing to coal fly ash and natural pozzolan Portland cements. J. Radioanal. Nucl. Chem. 325, 381-390. https:// doi.org/10.1007/s10967-020-07263-w.

108. Raghu, Y.; Ravisankar, R.; Chandrasekaran, A.; Vijayagopal, P.; Venkatraman, B. (2018) Assessment of natural radioactivity and radiological hazards in building materials used in the Tiruvannamalai District, Tamilnadu, India, using a statistical approach. J. Taibah Univ. Sci. 11 [4], 523-533. https://doi.org/10.1016/j.jtusci.2015.08.004.

109. Allard, B.; Olofsson, U.; Torstenfelt, B. (1984) Environmental actinide chemistry. Inor. Chimi. Acta. 94 [4], 205-221.

110. Plant, J.A.; Saunders, A.D. (1966) The Radioactive Earth. Radia. Protec. Dosi. 68 [1-2], 25-36. https://doi.org/ 10.1093/oxfordjournals.rpd.a031847.

111. Sanjuan, M.A.; Argiz, C.; Alonso, M.M.; Suarez-Navarro, J.A.; Gascó, C.; Puertas, F. (2019) Natural radioactivity of Portland cement mortars made with granite sand. $15^{\text {th }}$ International Congress on Chemistry of Cement (Prague).

112. Croymans, T.; Schroeyers, W.; Krivenko, P.; Kovalchuk, O.; Pasko, A.; Hult, M.; Marissens, G.; Lutter, G.; Schreurs, S. (2017) Radiological characterization and evaluation of high volume bauxite residue alkali activated concretes. J. Env. Rad. 168, 21-29. https://doi.org/10.1016/ j.jenvrad.2016.08.013.

113. Frutos Vázquez, B. (2009) Estudio experimental sobre la efectividad y la viabilidad de distintas soluciones constructivas para reducir la concentración de gas radón en edificaciones. PhD Thesis E.T.S. Arquitectura. Universidad Politécnica de Madrid. 